\title{
Regulatory T Cells Protect Fine Particulate Matter-Induced Inflammatory Responses in Human Umbilical Vein Endothelial Cells
}

\author{
Wen-cai Zhang, ${ }^{1}$ Yan-ge Wang, ${ }^{1}$ Zheng-feng $\mathrm{Zhu},{ }^{1}$ Fang-qin $\mathrm{Wu},{ }^{1}$ \\ Yu-dong Peng, ${ }^{1}$ Zhu-yue Chen, ${ }^{1}$ Jin-hua Yang, ${ }^{1}$ Jing-jing Wu, ${ }^{1}$ Yi-tian Lian, \\ Mei-an He, ${ }^{2}$ Tang-chun $\mathrm{Wu}^{2}$ and Long-xian Cheng ${ }^{1,3}$ \\ ${ }^{1}$ Laboratory of Cardiovascular Immunology, Institute of Cardiology, Union Hospital, Tongji Medical College of \\ Huazhong University of Science and Technology, Wuhan 430000, China \\ ${ }^{2}$ Institute of Occupational Medicine and the Ministry of Education Key Lab of Environment and Health, \\ Huazhong University of Science and Technology, Wuhan 430000, China \\ ${ }^{3}$ Institute of Cardiology, LIYUAN Hospital, Tongji Medical College of Huazhong University of Science and Technology, \\ Wuhan 430000, China
}

Correspondence should be addressed to Long-xian Cheng; chenglongxian@sina.com

Received 15 January 2014; Accepted 6 May 2014; Published 29 May 2014

Academic Editor: Marisa I. Gómez

Copyright (C) 2014 Wen-cai Zhang et al. This is an open access article distributed under the Creative Commons Attribution License, which permits unrestricted use, distribution, and reproduction in any medium, provided the original work is properly cited.

\begin{abstract}
Objective. To investigate the role of $\mathrm{CD} 4^{+} \mathrm{CD} 25^{+} \mathrm{T}$ cells (Tregs) in protecting fine particulate matter (PM-) induced inflammatory responses, and its potential mechanisms. Methods. Human umbilical vein endothelial cells (HUVECs) were treated with graded concentrations $\left(2,5,10,20\right.$, and $\left.40 \mu \mathrm{g} / \mathrm{cm}^{2}\right)$ of suspension of fine particles for $24 \mathrm{~h}$. For coculture experiment, HUVECs were incubated alone, with $\mathrm{CD} 4^{+} \mathrm{CD} 25^{-} \mathrm{T}$ cells (Teff), or with Tregs in the presence of anti-CD3 monoclonal antibodies for 48 hours, and then were stimulated with or without suspension of fine particles for 24 hours. The expression of adhesion molecules and inflammatory cytokines was examined. Results. Adhesion molecules, including vascular cell adhesion molecule-1 (VCAM-1) and intercellular adhesion molecule-1 (ICAM-1), and inflammatory cytokines, such as interleukin (IL-) 6 and IL-8, were increased in a concentration-dependent manner. Moreover, the adhesion of human acute monocytic leukemia cells (THP-1) to endothelial cells was increased and NF- $\kappa \mathrm{B}$ activity was upregulated in HUVECs after treatment with fine particles. However, after Tregs treatment, fine particles-induced inflammatory responses and NF- $\kappa \mathrm{B}$ activation were significantly alleviated. Transwell experiments showed that Treg-mediated suppression of HUVECs inflammatory responses impaired by fine particles required cell contact and soluble factors. Conclusions. Tregs could attenuate fine particles-induced inflammatory responses and NF- $\kappa$ B activation in HUVECs.
\end{abstract}

\section{Introduction}

Particulate air pollution caused by fine particles with aerodynamic diameters under $2.5 \mu \mathrm{m}\left(\mathrm{PM}_{2.5}\right)$ is well known to be associated with the morbidity and mortality of cardiovascular diseases $[1,2]$. Epidemiological studies have reported that fine particulate matter is a risk factor for the mortality of cardiovascular diseases through mechanisms that may include pulmonary and systemic inflammation, accelerated atherosclerosis, and altered cardiac autonomic functions [3]. Previous animal studies also showed that long-term exposure to low concentrations of $\mathrm{PM}_{2.5}$ caused significant increase in plaque areas and macrophage infiltration, likely via vascular inflammation, and increased the generation of reactive oxygen species $[4,5]$. In diabetes, exposure to $\mathrm{PM}_{2.5}$ has been found to induce excessive reactive oxygen species and endothelial dysfunction, which may in turn enhance the risk of cardiovascular diseases [6]. However, to date, the underlying pathophysiological mechanisms connecting fine particles and cardiovascular diseases, especially atherosclerosis, remain unclear.

Inhaled insoluble $\mathrm{PM}_{2.5}$ and smaller $\mathrm{PM}_{0.1}$ have been shown to quickly translocate into the circulation from lungs, 
with the potential exerting direct effects on homeostasis and cardiovascular integrity [7]. As a result, the barrier functions of the endothelium may be damaged by $\mathrm{PM}_{2.5}$ in the circulation. Several in vivo experiments previously found that intratracheal instillation with particles led to systemic microvascular dysfunction $[8,9]$. In addition, in vitro studies also suggested that particles may activate endothelial cells and induce the expression of adhesion molecules, including vascular cell adhesion molecule-1 (VCAM-1) and intercellular adhesion molecule-1 (ICAM-1), and inflammatory cytokines, such as interleukin (IL-) 6 and IL-8, in endothelial cells [1015]. Since endothelial activation may lead to an increased risk of cardiovascular events [16], the effects of particles (SRM2786 $<4 \mu \mathrm{m})$ used in this study on human umbilical vein endothelial cells (HUVECs) were first investigated by examining the expression of specific adhesion molecules and inflammatory cytokines.

Regulatory $\mathrm{T}$ (Treg) cells belong to a unique lineage of $\mathrm{T}$ cells that play an important role in the modulation of immune responses and the reduction of deleterious immune activation owing to their immunoregulatory and immunosuppressive functions [17]. A previous study showed that Treg cells were able to protect the proinflammatory activation in HUVECs exposed to oxidized low-density lipoprotein (ox-LDL) or lipopolysaccharide (LPS) by directly interacting with target endothelial cells and promoting the secretion of IL-10 and transforming growth factor- $\beta 1$ [18]. However, the role of Treg cells in fine particulate matter-induced inflammatory responses and endothelial functions has not yet been elucidated. Therefore, in the present study, we further observed the effects of Treg cells on fine particlesinduced inflammatory responses and endothelial functions in HUVECs and explored its potential mechanisms.

\section{Materials and Methods}

2.1. Ethical Statement. The investigation conforms to the principles outlined in the Declaration of Helsinki. The trial was approved by the ethics committee of Tongji Medical College of Huazhong University of Science and Technology. And all volunteers provided written informed consent to participate in the study.

2.2. Particle Samples. In this study, urban fine particulate matter $(<4 \mu \mathrm{m})$ (SRM2786) was obtained from the National Institute of Standards and Technology. The particles were treated by sonicating a $10000 \mu \mathrm{g} / \mathrm{mL}$ suspension in cell culture medium for $30 \mathrm{~min}$ in cycles for $10 \mathrm{~min}$ each, after which the suspension of particles was frozen and stored at $-20^{\circ} \mathrm{C}$. Before each experiment, the suspension was thawed and sonicated for $15 \mathrm{~min}$ and then immediately diluted to the assigned concentrations in cell culture medium.

2.3. HUVEC Cultures. HUVECs were derived from human umbilical veins that were cannulated, washed with Hanks' solution to wipe off blood, and then digested with $1 \%$ collagenase (Sigma, USA) for $15 \mathrm{~min}$ at $37^{\circ} \mathrm{C}$. After removal of collagenase, cells were incubated at $37^{\circ} \mathrm{C}$ on gelatincoated culture dishes in Ml99 medium (Gibco, USA) and supplemented with $20 \%$ fetal calf serum (Gibco), $100 \mu \mathrm{g} / \mathrm{mL}$ heparin (Sigma), $50 \mu \mathrm{g} / \mathrm{mL}$ endothelial cell growth factor (Gibco), $25 \mathrm{mM}$ Hepes buffer, $2 \mathrm{mM}$ L-glutamine, 100 $\mathrm{U} / \mathrm{mL}$ penicillin, and $100 \mathrm{U} / \mathrm{mL}$ streptomycin, as previously described [19]. Cells between passages 2 and 6 were used for experiments. The phenotype of HUVECs was verified by von Willebrand antigen staining.

2.4. THP-1 Cultures. The monocytic cell line THP-1 was obtained from the American Type Culture Collection (Manassas, USA) and cultured in RPMI1640 with 10\% fetal calf serum.

2.5. Isolation and Purification of Tregs. Peripheral blood was collected from 20 normal volunteers, and peripheral blood mononuclear cells (PBMCs) were isolated using Ficoll-Paque PLUS (GE Healthcare, USA). Treg cells were subsequently isolated using the Human $\mathrm{CD} 4^{+} \mathrm{CD} 25^{+}$Regulatory T Cell Isolation Kit (Miltenyi Biotec, Germany) according to the manufacturer's instructions. In brief, PBMCs were labeled with a mixture of biotin-conjugated antibodies and antibiotin microbeads, and $\mathrm{CD} 4^{+}$cells were then obtained by negative selection. Next, $\mathrm{CD} 4^{+} \mathrm{CD} 25^{+}$Treg cells were isolated twice by positive selection to achieve higher purity. The purity of the $\mathrm{CD} 4^{+} \mathrm{CD} 25^{+}$cell population was $>90 \%$ as assessed by FACS.

2.6. Functional Suppression Assays. $\mathrm{CD} 4^{+} \mathrm{CD} 25^{-} \mathrm{T}$ cells (Teff) and $\mathrm{CD} 4{ }^{+} \mathrm{CD} 25^{+} \mathrm{T}$ cells (Tregs) were cocultured in 96-well plates coated with $50 \mathrm{ng} / \mathrm{mL}$ anti-CD3 mAb (eBioscience, USA) at a density of $10^{4}$ cells/well with different Teff/Treg ratios $(1: 1,1: 1 / 2,1: 1 / 4$, and $1: 1 / 8)$. All wells were cultured in a final volume of $200 \mu \mathrm{L}$ with the presence of $\mathrm{T}$ cell-depleted and irradiated antigen presenting cells $\left(10^{5}\right.$ cells/well). After $72 \mathrm{~h}$, [3H]-thymidine $(1 \mu \mathrm{Ci} /$ well $)$ was added for $16 \mathrm{~h}$ prior to the determination of proliferation by scintillation counting (MicroBeta1450 Liquid Scintillation Counter; Perkin Elmer, USA). Percent inhibition of proliferation was determined as follows: $(1-[3 \mathrm{H}]$-thymidine uptake of cocultured Treg and Teff)/Teff alone $\times 100 \%$. Triplicate wells were used in all suppression experiments.

2.7. Cells Stimulations. Confluent HUVECs were growth arrested by serum deprivation for $24 \mathrm{~h}$. In order to explore the optimum concentration of the particles to stimulate HUVECs, cells were treated with graded concentration (2, $5,10,20$, and $40 \mu \mathrm{g} / \mathrm{cm}^{2}$ ) of suspension of the particles for $24 \mathrm{~h}$. In some experiment, cells were pretreated for $30 \mathrm{~min}$ with the NF- $\kappa$ B inhibitor PDTC $(10 \mu \mathrm{mol} / \mathrm{L})$ (Sigma, USA) before stimulation with PM $\left(20 \mu \mathrm{g} / \mathrm{cm}^{2}\right)$ for $24 \mathrm{~h}$. Sometimes, LPS $(1 \mu \mathrm{g} / \mathrm{mL})$ was selected as a positive control. Then, the cells were harvested and supernatant was collected for further assay.

2.8. Coculture of HUVECs and Tregs. For synchronization, HUVECs were cultured in 6-well plates containing serumfree medium for $24 \mathrm{~h}$ when the cells were grown to $80-90 \%$ 
TAble 1: Primers used for real-time PCR and the size of products.

\begin{tabular}{lccc}
\hline Genes & Forward $\left(5^{\prime}-3^{\prime}\right)$ & Reverse $\left(5^{\prime}-3^{\prime}\right)$ & Size $(\mathrm{bp})$ \\
\hline VCAM-1 & TAAAATGCCTGGGAAGATGG & GGTGCTGCAAGTCAATGAGA & 151 \\
ICAM-1 & CAGAGGTTGAACCCCACAGT & CCTCTGGCTTCGTCAGAATC & 196 \\
IL-6 & CAAATTCGGTACATCCTCGACGGC & GGTTCAGGTTGTTTTCTGCCAGTGC \\
IL-8 & TAGCAAAATTGAGGCCAAGG & AAACCAAGGCACAGTGGAAC & 109 \\
$\beta$-actin & AGTGTGACGTGGACATCCGC & ACTCGTCATACTCCTGCTTGCTG & 227 \\
\hline
\end{tabular}

confluence. Nonadherent cells were washed off with PBS, and new culture medium was replaced. Next, HUVECs and T cells $(2: 1)$ were cocultured as previously described [20]. Briefly, HUECVs $\left(1 \times 10^{6} /\right.$ well $)$ were incubated alone or with $\mathrm{CD} 4^{+} \mathrm{CD} 25^{-}$or $\mathrm{CD} 4^{+} \mathrm{CD} 25^{+} \mathrm{T}$ cells for $48 \mathrm{~h}$ in the presence of $50 \mathrm{ng} / \mathrm{mL}$ anti-CD3 mAb, followed by addition of PM $\left(20 \mu \mathrm{g} / \mathrm{cm}^{2}\right)$ or LPS $(1 \mu \mathrm{g} / \mathrm{mL})$ for another $24 \mathrm{~h}$. After incubation, floating $\mathrm{T}$ cells were discarded, and HUVECs were washed with PBS and harvested. Finally, supernatants were collected and kept frozen at $-80^{\circ} \mathrm{C}$ for further experiments.

2.9. Flow Cytometry for Detection of VCAM-1. After the coculture period, HUVECs were digested with $0.25 \%$ trypsin without EDTA and washed two times with PBS. Cells were then stained with PE-anti-human VCAM-1 antibody (eBioscience, USA) for $30 \mathrm{~min}$ at $4^{\circ} \mathrm{C}$. Isotype control antibodies were used to ensure antibody specificity. Stained cells were detected by a FACSAria flow cytometer (BD Biosciences, USA), and the percentage of positive cells was analyzed by FlowJo 7.6.1.

2.10. Enzyme-Linked Immunosorbent Assay. Supernatants derived from different groups were subjected to specific ELISA assays (all from R\&D Systems, USA) according to the manufacturer's instructions. The minimum detectable concentrations for sVCAM-1, sICAM-1, IL-6, IL-8, TGF$\beta 1$, and IL-10 were $1.26 \mathrm{ng} / \mathrm{mL}, 0.254 \mathrm{ng} / \mathrm{mL}, 0.7 \mathrm{pg} / \mathrm{mL}$, $7.5 \mathrm{pg} / \mathrm{mL}, 15.4 \mathrm{pg} / \mathrm{mL}$, and $3.9 \mathrm{pg} / \mathrm{mL}$, respectively. The intraassay and interassay coefficients of variation for these ELISA assays were $<5 \%$ and $<10 \%$, respectively. All measurements were taken twice.

2.11. Real-Time PCR. Total RNA of HUVECs from different groups was extracted using Trizol Reagent (Takara, Japan) according to the manufacturer's instruction and then subjected to cDNA synthesis using the RNA PCR Kit (Takara). The mRNA expression was determined with the use of SYBR Green Master Mix (Takara) on an ABI Prism 7900 sequence detection system (Applied Biosystems, USA). For each sample, the mRNA expression was normalized to $\beta$ actin. Primers used in this study were shown in Table 1.

2.12. Adhesion of THP-1 Cells to Endothelial Cells. After the coculture period, THP-1 cells were labeled with CFSE (Sigma, USA) according to the manufacturer's instructions and added to endothelial cell monolayers grown in 24-well plates at a monocyte-to-endothelial cell ratio of $10: 1$. After a $1 \mathrm{~h}$ culture at $37^{\circ} \mathrm{C}$, suspension cells were removed by three washes with PBS. Subsequently, cells were fixed with $4 \%$ paraformaldehyde, and the number of green fluorescent adherent cells was counted in five randomly chosen fields under a fluorescence microscope.

2.13. Transwell Experiment. Transwell experiments were conducted in 24 -well plates $(0.4 \mu \mathrm{m}$ pore size, Corning Costar, USA) by culturing HUVECs $\left(1 \times 10^{6} / \mathrm{mL}\right)$ in the lower well and the Treg cells $\left(5 \times 10^{5} / \mathrm{mL}\right)$ with anti-CD3 $\mathrm{mAb}$ in the inserts. After $48 \mathrm{~h}$ of culture, the inserts were removed, and the HUVECs in the lower well were stimulated with PM $\left(20 \mu \mathrm{g} / \mathrm{cm}^{2}\right)$ for $24 \mathrm{~h}$. For neutralization experiments, neutralizing antibodies against IL-10 $(5 \mu \mathrm{g} / \mathrm{mL})$, TGF- $\beta 1$ $(5 \mu \mathrm{g} / \mathrm{mL})$, or isotype control $(5 \mu \mathrm{g} / \mathrm{mL})$ (all from $\mathrm{R} \& \mathrm{D}$ Systems, USA) were added at the start of the coculture in the lower wells. After the incubation period, HUVECs and supernatants were collected for further experiments.

2.14. Electrophoretic Mobility Shift Assay (EMSA) for Detection of $N F-\kappa B$. For the EMSA assay, nuclear proteins were extracted from different groups using the Nuclear and Cytoplasmic Protein Extraction Kit (Beyotime Institute of Biotechnology, China). DNA-protein interactions were detected using the LightShift Chemiluminescent EMSA Kit (Pierce, USA) according to the manufacturer's instructions. The consensus sequences of biotin-labeled NF- $\kappa$ B oligonucleotides were as follows: forward, $5^{\prime}$-AGTTGAGGGGACTTTCCCAGGC-3' ${ }^{\prime}$, and reverse, $5^{\prime}$-GCCTGGGAAAGTCCCCTCAACT $-3^{\prime}$. Biotin end-labeled DNA was detected by chemiluminescence. To verify whether detected shifted bands were specific for NF- $\kappa \mathrm{B}$, competition tests were conducted with the use of a 200-fold excess of unlabeled "cold" oligonucleotides, in addition to labeled probes.

2.15. Statistical Analysis. Data are shown as means \pm SEM. Differences were evaluated using one-way ANOVA for multiple comparisons, followed by the post hoc Student-NewmanKeuls test when necessary. All analyses were done using SPSS 16.0, and statistical significance was set at $P<0.05$.

\section{Results}

3.1. Identification of $\mathrm{CD} 4^{+} \mathrm{CD} 25^{+} \mathrm{T}$ Cells. By flow cytometry, the purity of $\mathrm{CD} 4^{+} \mathrm{CD} 25^{+}$Tregs isolated from peripheral blood mononuclear cells was found to be $>90 \%$ (Figure 1(a)), and most of the isolated Tregs were Foxp $3^{+}$(Figure 1(b)). To test whether the cells with the phenotype of $\mathrm{CD} 4^{+} \mathrm{CD} 25^{+} \mathrm{T}$ cells had functional characteristics of Tregs, we cocultured 


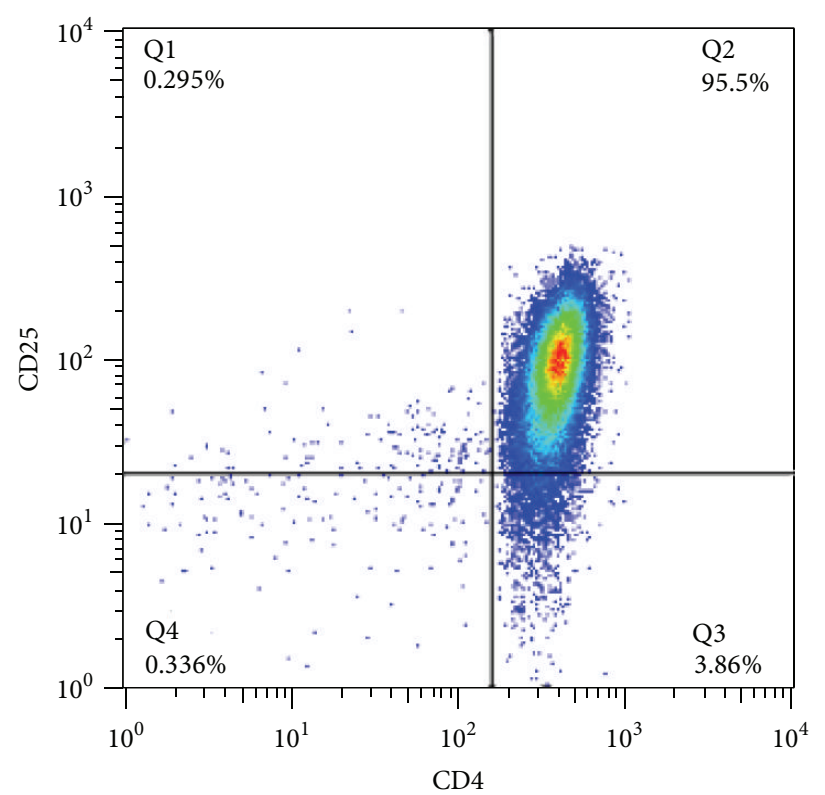

(a)

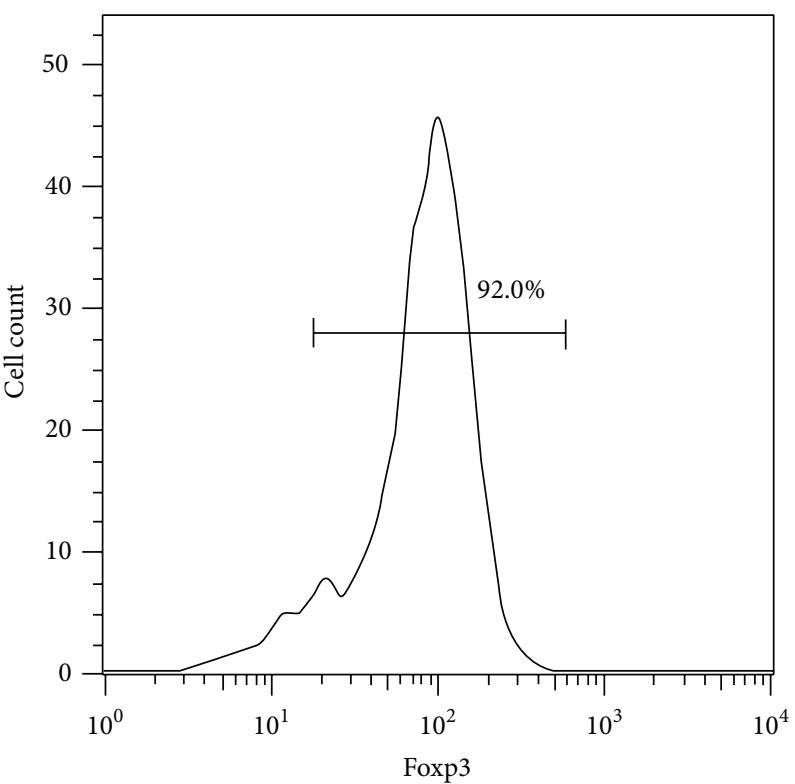

(b)

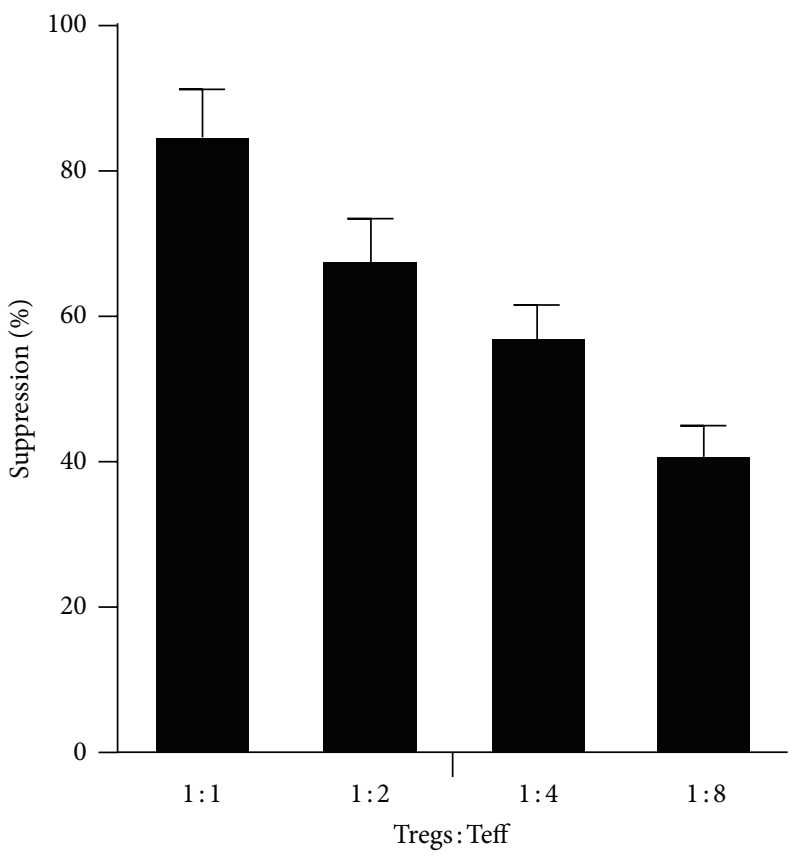

(c)

FIGURE 1: Isolation and identification of $\mathrm{CD}^{+} \mathrm{CD} 25^{+} \mathrm{T}$ cells. (a) The purity of $\mathrm{CD} 4^{+} \mathrm{CD} 25^{+} \mathrm{T}$ cells isolated from peripheral blood mononuclear cells (PBMCs) of healthy volunteers was examined by flow cytometry. (b) The percentage of the foxp $3^{+}$population among the sorted $\mathrm{CD} 4^{+} \mathrm{CD} 25^{+}$T cells. (c) Proliferation was evaluated by thymidine incorporation. The relative effect of $\mathrm{CD} 4^{+} \mathrm{CD} 25^{+} \mathrm{T}$ cells was expressed as percentage inhibition of $\mathrm{CD} 4^{+} \mathrm{CD} 25^{-} \mathrm{T}$ cells. Experiments were repeated 3 times.

them with $\mathrm{CD} 4^{+} \mathrm{CD} 25^{-} \mathrm{T}$ cells at different ratios and assessed their capacity to suppress the proliferation of autologous $\mathrm{CD} 4^{+} \mathrm{CD} 25^{-} \mathrm{T}$ cells after activation with anti-CD3 $\mathrm{mAb}$. As expected, Tregs were able to efficiently suppress the proliferation of $\mathrm{CD} 4^{+} \mathrm{CD} 25^{-} \mathrm{T}$ cells in a dose-dependent manner (Figure 1(c)).
3.2. PM Induces HUVECs Inflammatory Responses in a Concentration-Dependent Manner. It has been reported that PM from different sources causes adhesion molecules and cytokines expression in ECs [10-15]. However, the effect of the particles used in this study in HUVECs was not determined before. Therefore, in this study, we first investigated the effects 


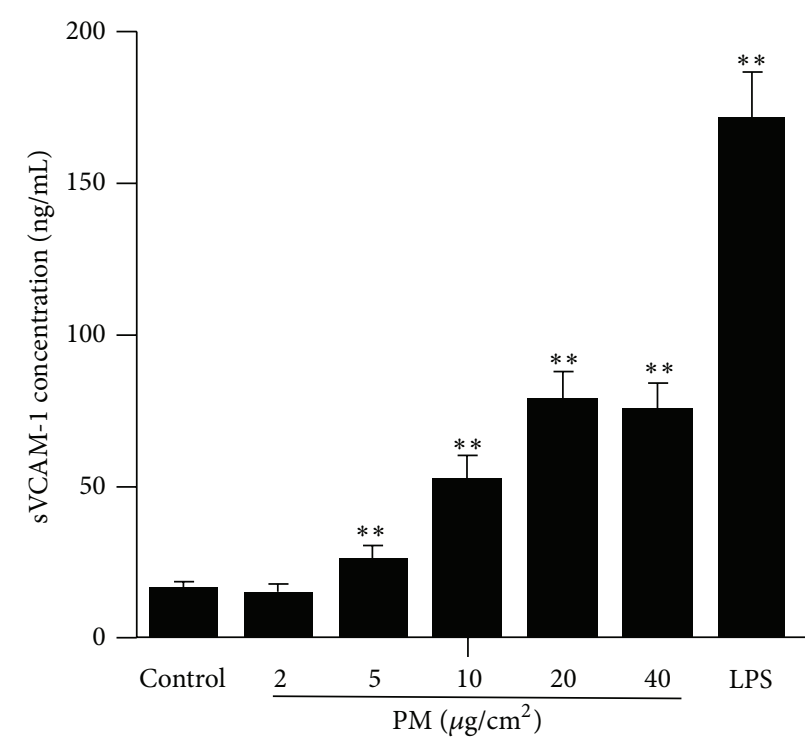

(a)

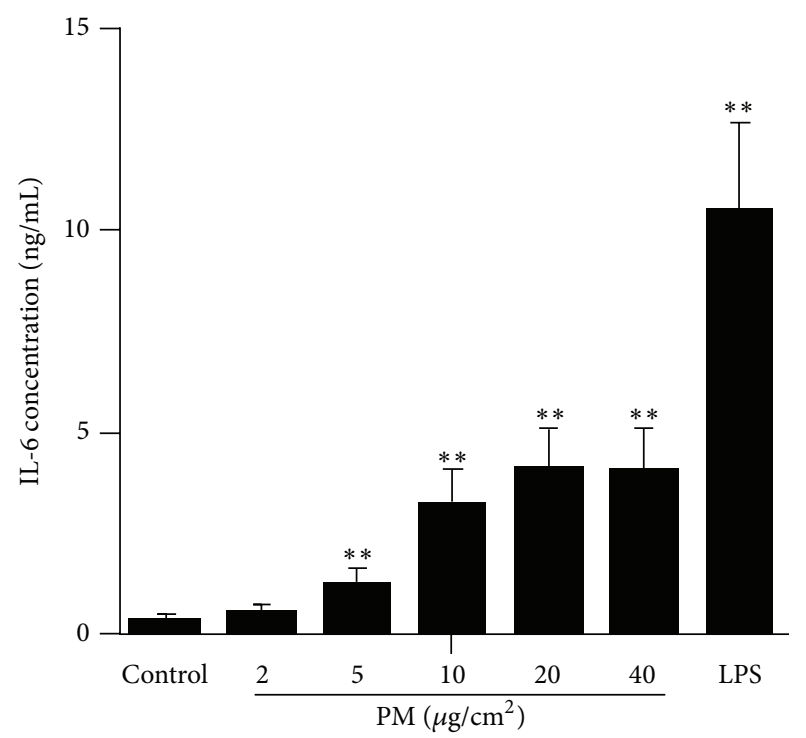

(c)

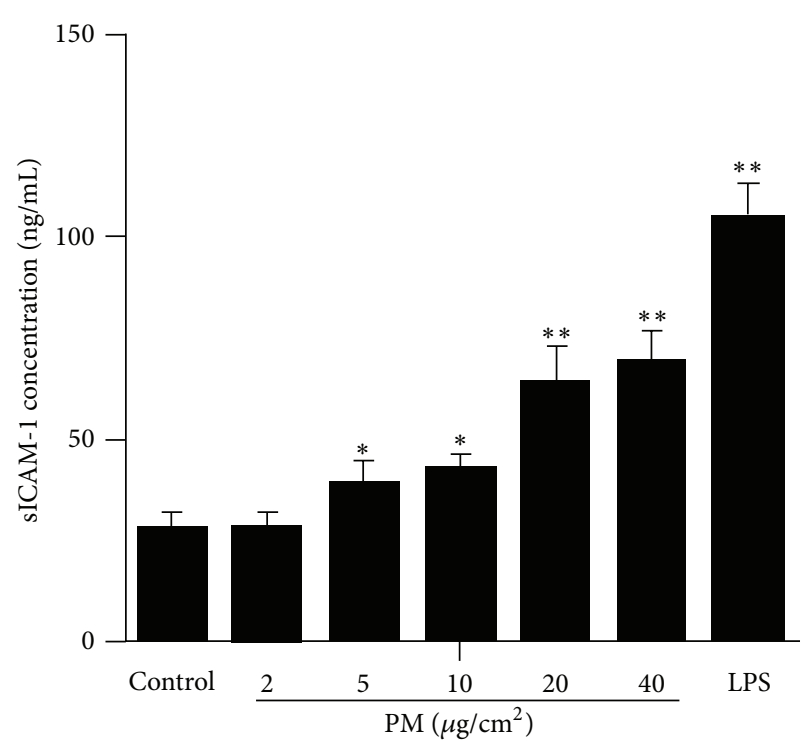

(b)

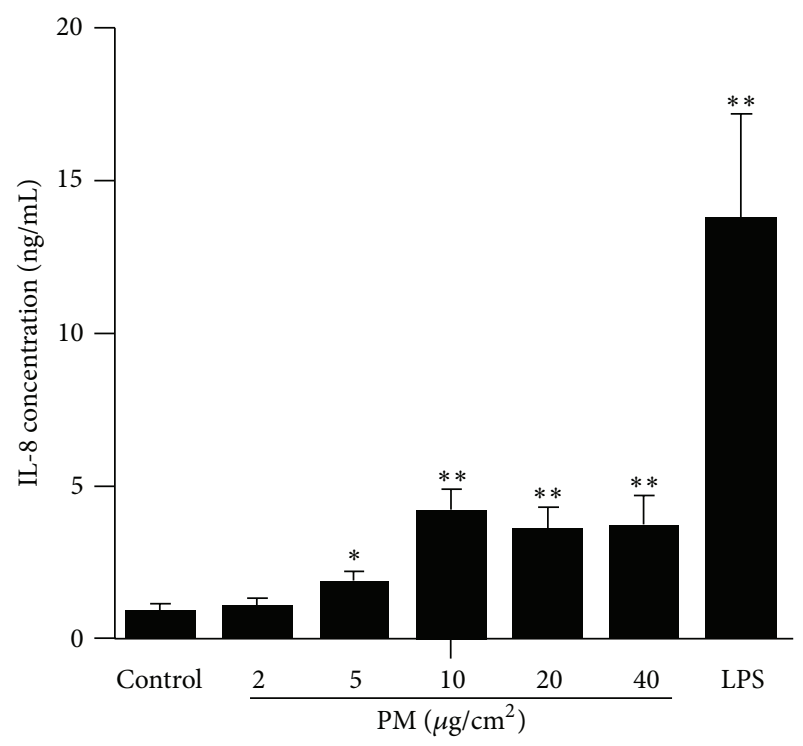

(d)

FIGURE 2: PM induces HUVECs inflammatory responses in a concentration-dependent manner. HUVECs were treated with graded concentration $\left(2,5,10,20\right.$, and $\left.40 \mu \mathrm{g} / \mathrm{cm}^{2}\right)$ of suspension of the particles for $24 \mathrm{~h}$ and the supernatant was collected. The concentration of sVCAM-1 (a), sICAM-1 (b), IL-6 (c), and IL-8 (d) was detected by Elisa. ${ }^{*}$ indicates PM or LPS versus control. ${ }^{*} P<0.05 ;{ }^{* *} P<0.01$. Experiments were repeated 3 times.

of the particles on HUVECs by examining the expression of specific adhesion molecules (VCAM-1 and ICAM-1) and inflammatory cytokines (IL-6 and IL-8). We examined PMinduced HUVECs adhesion molecules and inflammatory cytokines expression after $24 \mathrm{~h}$ of stimulation with 2, 5, 10, 20, and $40 \mu \mathrm{g} / \mathrm{cm}^{2}$. We found that particles induced inflammatory responses in a concentration-dependent manner beginning at $5 \mu \mathrm{g} / \mathrm{cm}^{2}$ (Figure 2). The optimum concentration of PM-induced HUVECs VCAM-1, ICAM-1, IL-6, and IL8 expression was $20,40,20$, and $10 \mu \mathrm{g} / \mathrm{cm}^{2}$, respectively (Figure 2). Thus, we used the concentration of $20 \mu \mathrm{g} / \mathrm{cm}^{2}$ to stimulate cells for further experiment.
3.3. Tregs Alleviate VCAM-1 Expression in PM-Exposed HUVECs. HUVECs were culture alone or cocultured with $\mathrm{CD} 4^{+} \mathrm{CD} 25^{-} \mathrm{T}$ cells (Teff) or Tregs in the presence of anti-CD3 $\mathrm{mAb}$ for $48 \mathrm{~h}$ and then treated with or without (control) PM/LPS for another $24 \mathrm{~h}$. After the coculture time, the VCAM-1 expression in HUVECs exposed to PM was detected by flow cytometry. The results show that the VCAM1 expression was significantly upregulated after $24 \mathrm{~h}$ of PM exposure in the absence of T cells, compared to the control $(22.4 \% \pm 1.9 \%$ versus $0.42 \% \pm 0.12 \% ; P<0.01$; Figures $3(\mathrm{a})$ and $3(\mathrm{~b}))$. What is more, we found that Tregs-treated HUVECs showed dramatically reduced VCAM-1 expression 

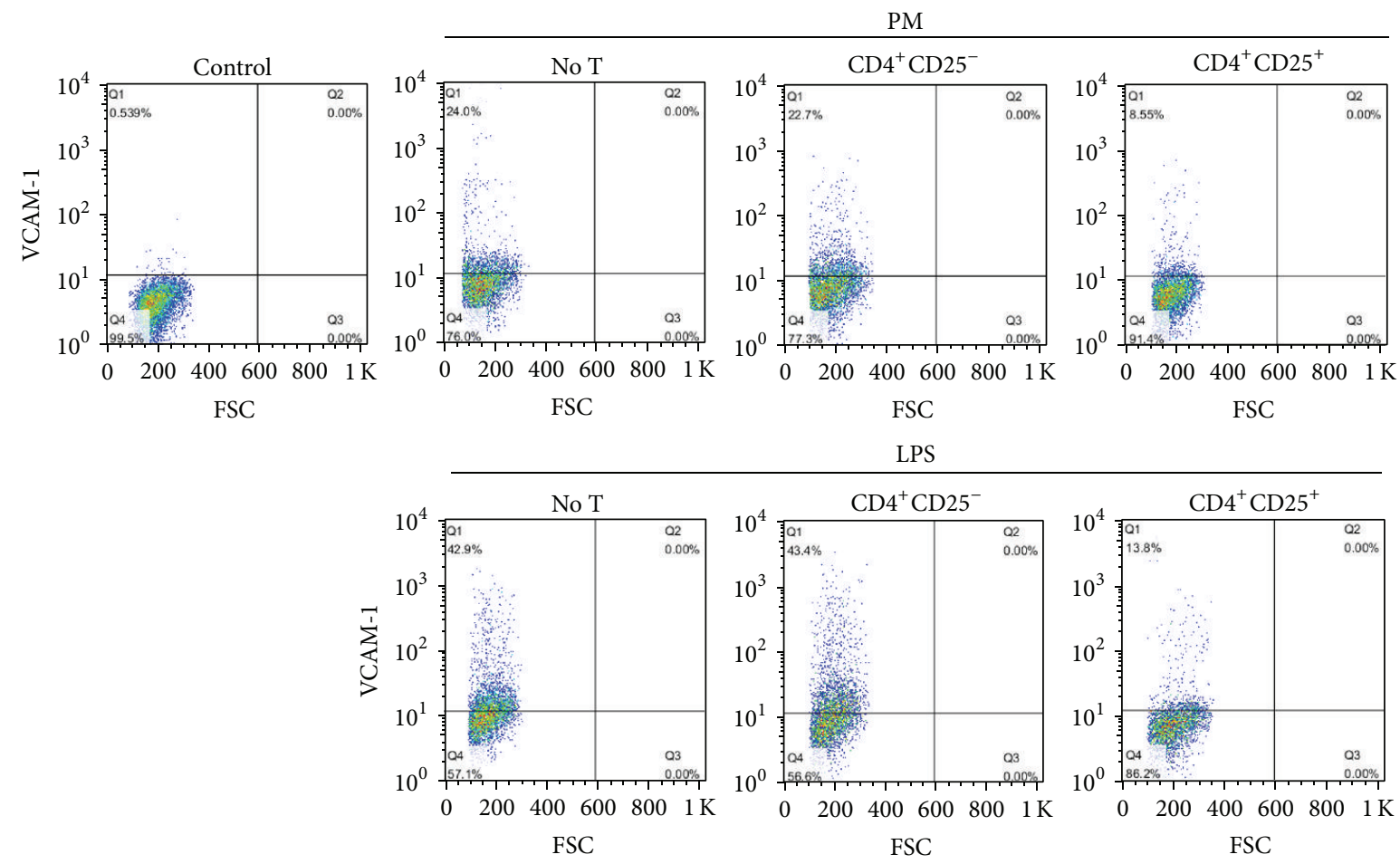

(a)

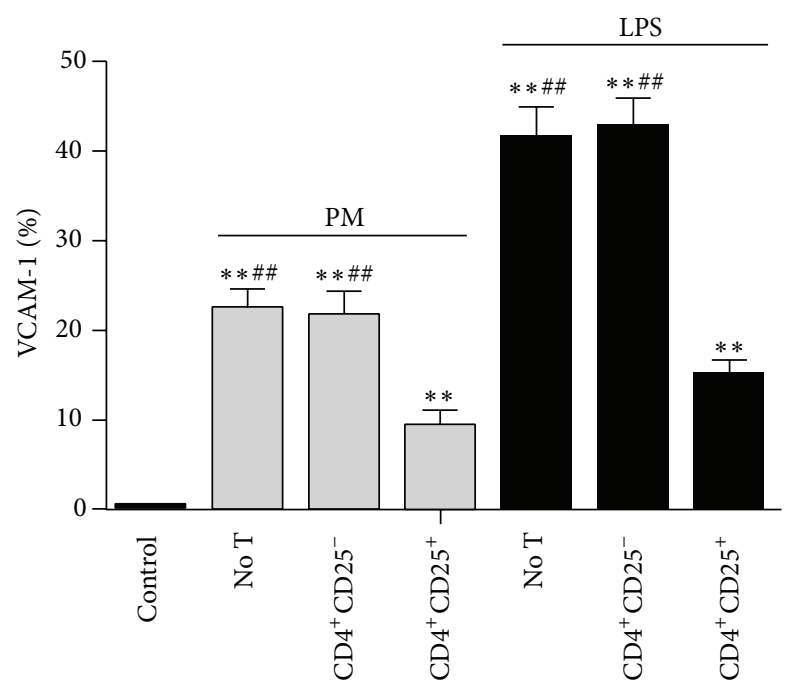

(b)

FIgURE 3: Tregs alleviate the expression of VCAM-1 in PM-exposed HUVECs. After the coculture period, HUVECs from different groups were harvested, and the VCAM-1 expression was detected by flow cytometry. (a) Dot plots showing the percentages of VCAM-1 expression in HUVECs. (b) The VCAM-1 expression in different groups of HUVECs. Data are expressed as means \pm SEM. ${ }^{*}$ indicates no T, CD ${ }^{+} \mathrm{CD} 25^{-}$, or $\mathrm{CD} 4{ }^{+} \mathrm{CD} 25^{+}$versus control; ${ }^{\#}$ indicates no $\mathrm{T}$ or $\mathrm{CD} 4^{+} \mathrm{CD} 25^{-}$versus $\mathrm{CD} 4{ }^{+} \mathrm{CD} 25^{+} ;{ }^{* *} P<0.01 ;{ }^{\# \#} \mathrm{P}<0.01$. Experiments were repeated 6 times.

$(\mathrm{PM}, 9.3 \% \pm 1.5 \%$; LPS, $14.9 \% \pm 1.8 \%)$, compared to the group without T cells (PM, 22.4\% $\pm 1.9 \%$; LPS, $41.4 \% \pm 3.5 \%$; $P<0.01)$ or the coculture group with $\mathrm{CD} 4{ }^{+} \mathrm{CD} 25^{-} \mathrm{T}$ cells (PM, 21.7\% $\pm 2.4 \%$; LPS, $42.6 \% \pm 3.3 \% ; P<0.01$ ) (Figures $3(\mathrm{a})$ and $3(\mathrm{~b}))$.

3.4. Tregs Downregulate Adhesion Molecules and Inflammatory Cytokines in PM-Exposed HUVECs. After the coculture period, the ELISA assay was used to detect the concentration of adhesion molecules and inflammatory cytokines. The results show that the suspension of fine particles and LPS significantly increased the protein levels of sVCAM-1 (PM, $77.2 \pm 9.5 \mathrm{ng} / \mathrm{mL}$; LPS, $154.7 \pm 16.2 \mathrm{ng} / \mathrm{mL})$, sICAM-1 (PM, $61.4 \pm 7.9 \mathrm{ng} / \mathrm{mL}$; LPS, $102.5 \pm 12.1 \mathrm{ng} / \mathrm{mL})$, IL-6 (PM, $4.0 \pm$ $1.2 \mathrm{ng} / \mathrm{mL}$; LPS, $9.8 \pm 2.5 \mathrm{ng} / \mathrm{mL}$ ), and IL-8 (PM, $3.4 \pm$ $0.7 \mathrm{ng} / \mathrm{mL}$; LPS, $15.7 \pm 3.7 \mathrm{ng} / \mathrm{mL}$ ), compared to the control 


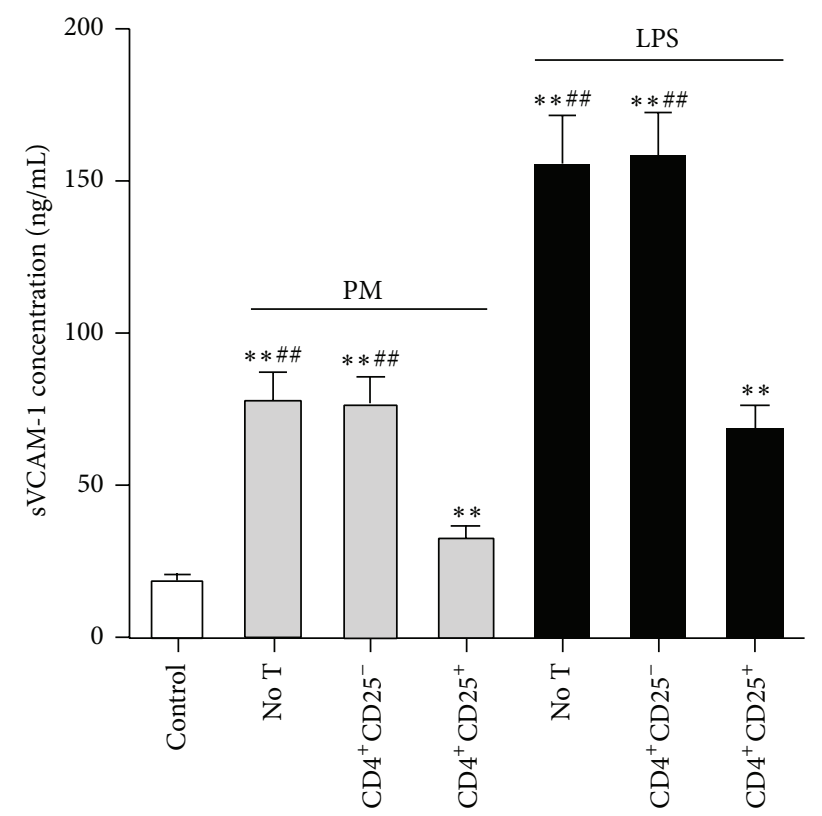

(a)

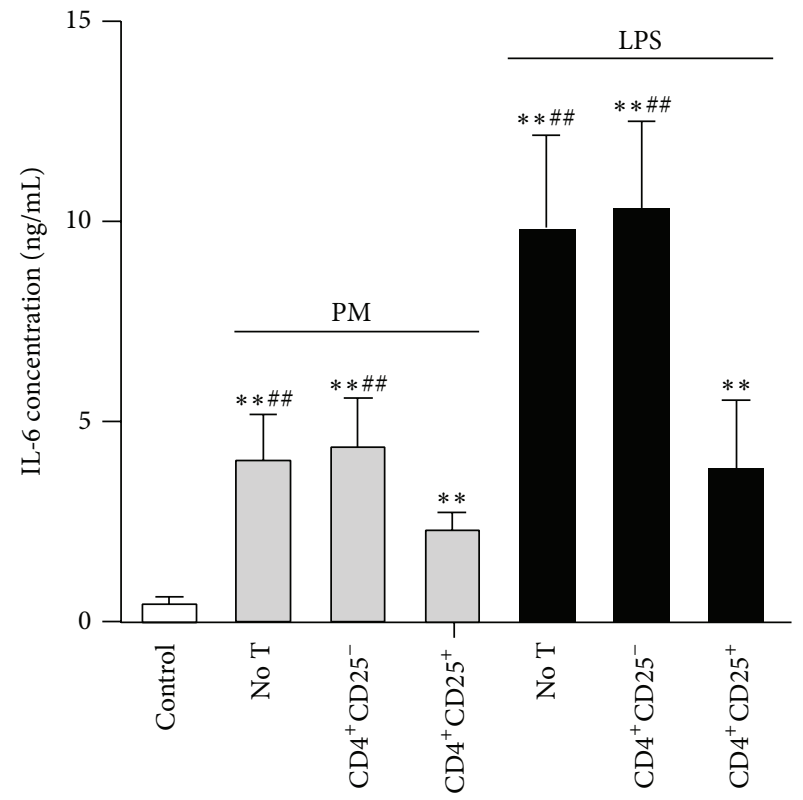

(c)

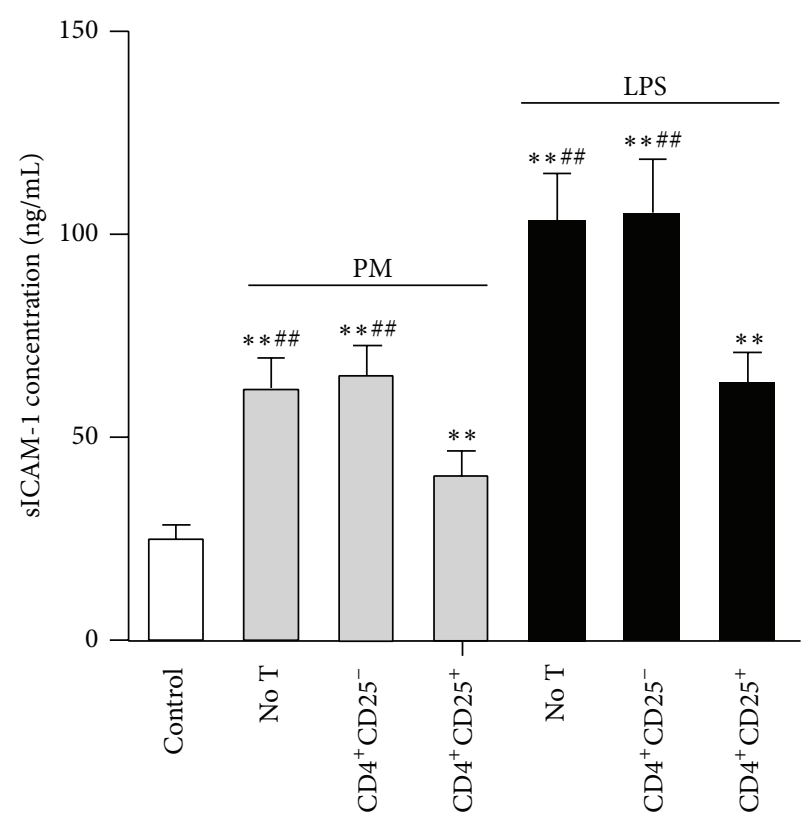

(b)

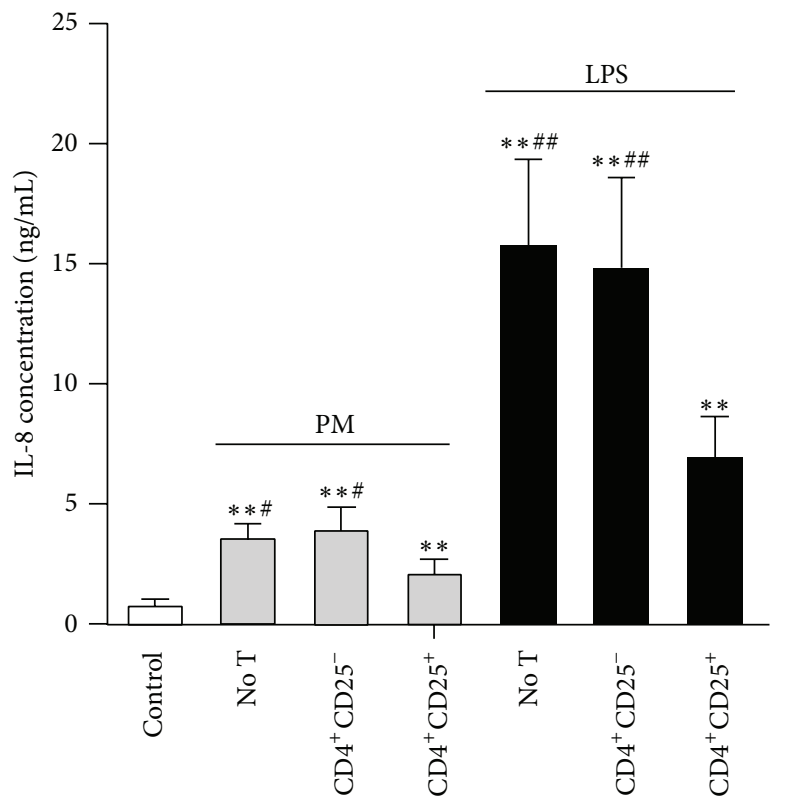

(d)

FIGURE 4: Tregs downregulate the protein expression of adhesion molecules and inflammatory cytokines in PM-exposed HUVECs. The ELISA assay was used to detect the concentration of sVCAM-1 (a), sICAM-1 (b), IL-6 (c), and IL-8 (d) in the supernatants from different groups of HUVECs. Data are expressed as means \pm SEM. ${ }^{*}$ indicates no T, $\mathrm{CD} 4{ }^{+} \mathrm{CD} 25^{-}$, or $\mathrm{CD} 4{ }^{+} \mathrm{CD} 25^{+}$versus control; ${ }^{\#}$ indicates no T or $\mathrm{CD} 4{ }^{+} \mathrm{CD} 25^{-}$versus $\mathrm{CD} 4{ }^{+} \mathrm{CD} 25^{+} .{ }^{*} P<0.05,{ }^{* *} P<0.01,{ }^{\#} P<0.05$, and ${ }^{\# \#} P<0.01$. Experiments were repeated 5 times.

$(18.4 \pm 2.7 \mathrm{ng} / \mathrm{mL}, 24.7 \pm 3.2 \mathrm{ng} / \mathrm{mL}, 5.1 \pm 1.1 \mathrm{ng} / \mathrm{mL}, 0.45 \pm$ $0.21 \mathrm{ng} / \mathrm{mL}$, and $0.84 \pm 0.29 \mathrm{ng} / \mathrm{mL}$, resp.) (all $P<0.01$; Figure 4). In addition, compared to the group without $\mathrm{T}$ cells, Tregs-treated HUVECs exhibited markedly decreased concentrations of all adhesion molecules and inflammatory cytokines $(P<0.05)$, whereas $\mathrm{CD} 4^{+} \mathrm{CD} 25^{-} \mathrm{T}$ cells had no effect $(P>0.05$; Figure 4$)$.

The mRNA levels of VCAM-1, ICAM-1, IL-6, and IL8 were also determined by real-time PCR (RT-PCR), and the results were normalized to the endogenous control gene $\beta$-actin. Consistent with the protein expression results described above, the mRNA levels of VCAM-1, ICAM-1, IL6 , and IL- 8 were all increased upon PM/LPS stimulation, and Tregs were able to dramatically reduce these upregulated mRNA levels (all $P<0.05$; Figure 5).

3.5. Tregs Decrease the Adhesion of THP-1 Cells to Endothelial Cells. To further confirm the increases in the expression of 


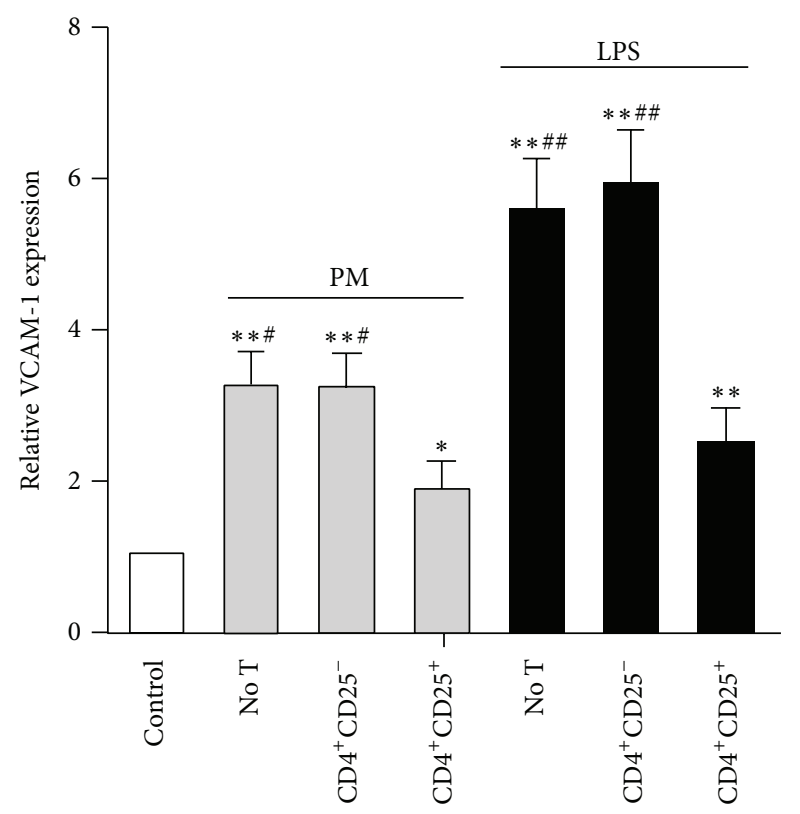

(a)

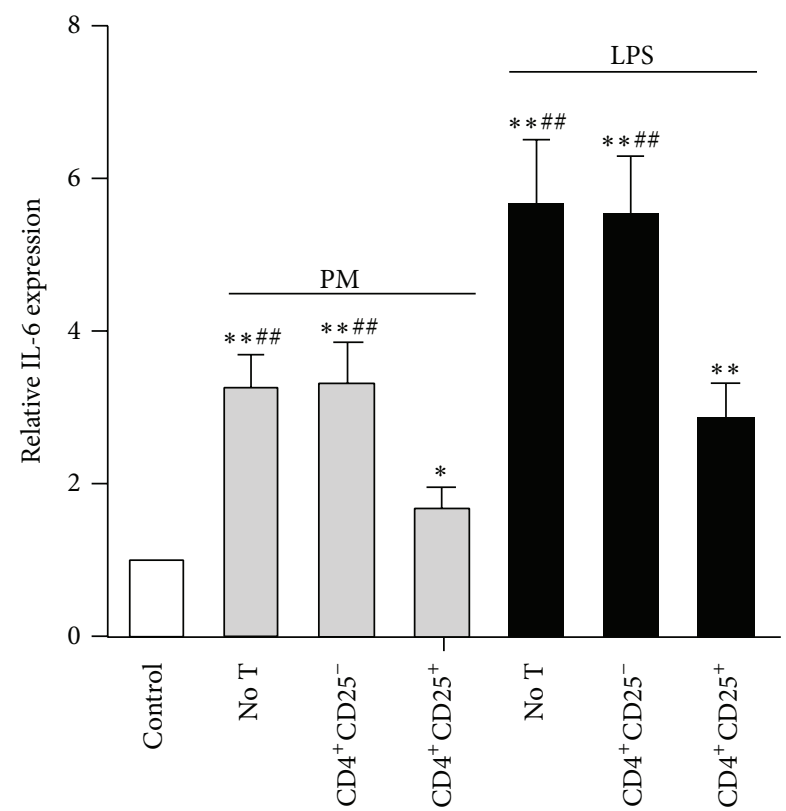

(c)

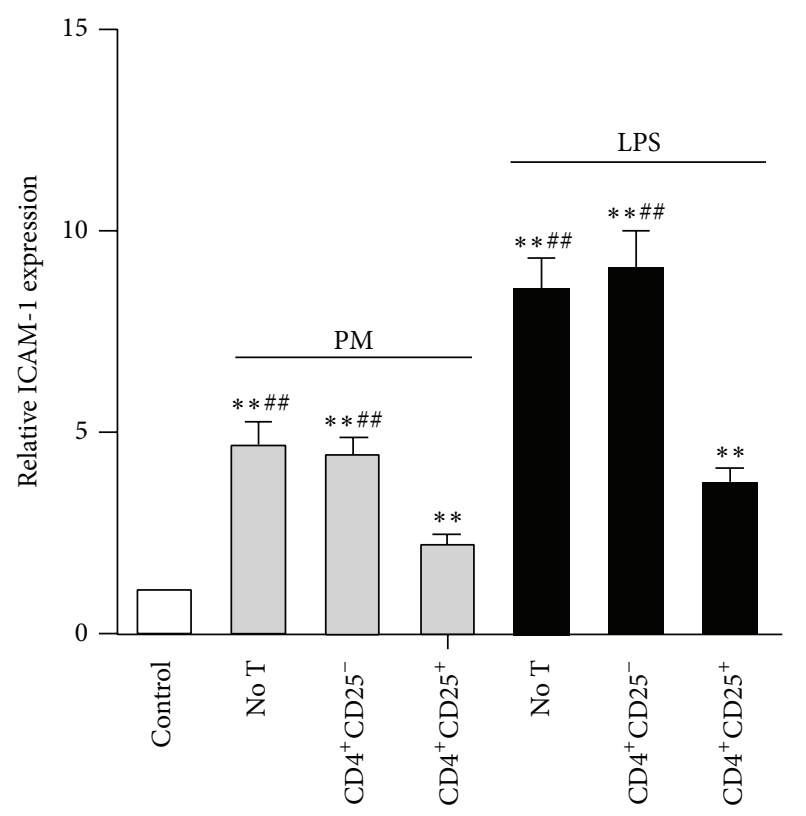

(b)

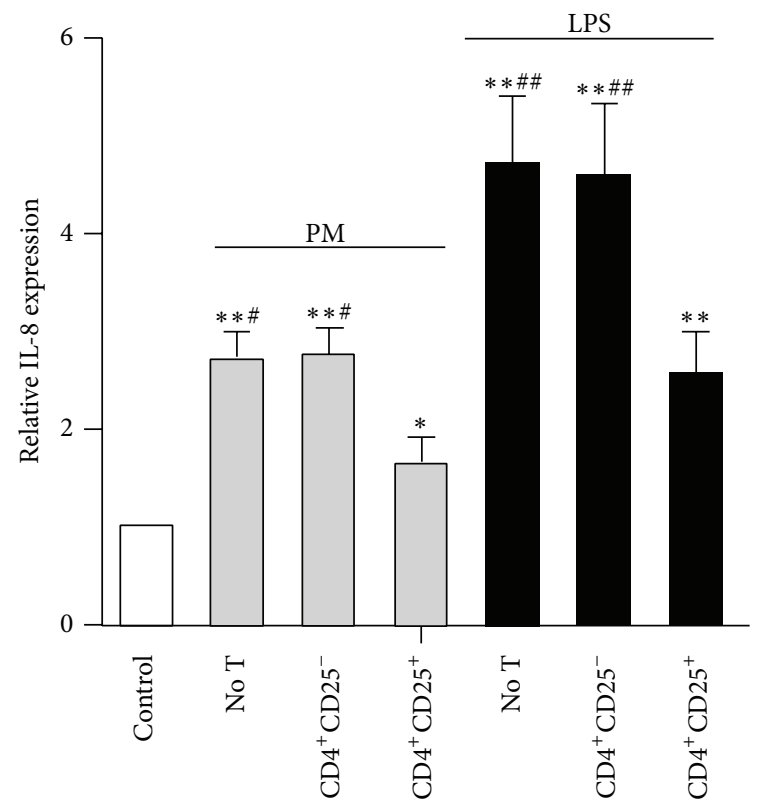

(d)

FIgURE 5: Tregs downregulate the mRNA expression of adhesion molecules and inflammatory cytokines in PM-exposed HUVECs. RTPCR was used to detect the mRNA expression of VCAM-1 (a), ICAM-1 (b), IL-6 (c), and IL-8 (d) in different groups of HUVECs. Data are expressed as means \pm SEM. ${ }^{*}$ indicates no T, $\mathrm{CD} 4^{+} \mathrm{CD} 25^{-}$, or $\mathrm{CD} 4{ }^{+} \mathrm{CD} 25^{+}$versus control; ${ }^{*}$ indicates no $\mathrm{T}$ or $\mathrm{CD} 4^{+} \mathrm{CD} 25^{-}$versus $\mathrm{CD} 4{ }^{+} \mathrm{CD} 25^{+}$. ${ }^{*} P<0.05,{ }^{* *} P<0.01,{ }^{\#} P<0.05$, and ${ }^{\# \#} P<0.01$. Experiments were repeated 5 times.

adhesion molecules VCAM-1 and ICAM-1 in HUVECs after PM exposure, the adhesion of THP-1 cells to endothelial cells was evaluated. After the coculture period, the THP1 cells labeled with CFSE were added to the HUVECs. As expected, the adhesion of THP-1 cells to endothelial cells was significantly increased (PM, $168 \pm 5.6$; LPS, $204 \pm 6.9)$, compared to the control $(67 \pm 3.5)(P<0.01$; Figures $6(\mathrm{a})$ and $6(\mathrm{~b})$ ). In contrast, the adhesion of THP-1 cells to Tregtreated HUVECs was obviously reduced (PM, $93 \pm 3.8$; LPS,
$127 \pm 4.5)(P<0.01)$, while $\mathrm{CD} 4^{+} \mathrm{CD} 25^{-} \mathrm{T}$ cells only had a minor effect $(P M, 171 \pm 5.4$; LPS, $211 \pm 7.2)(P>0.05$; Figures 6(a) and 6(b)).

3.6. PDTC Inhibits PM-Induced Inflammatory Responses. $\mathrm{NF}-\kappa \mathrm{B}$ is a transcription factor that regulates the expression of proinflammatory and antiapoptotic genes and also plays an important role in driving the inflammatory responses [21]. 


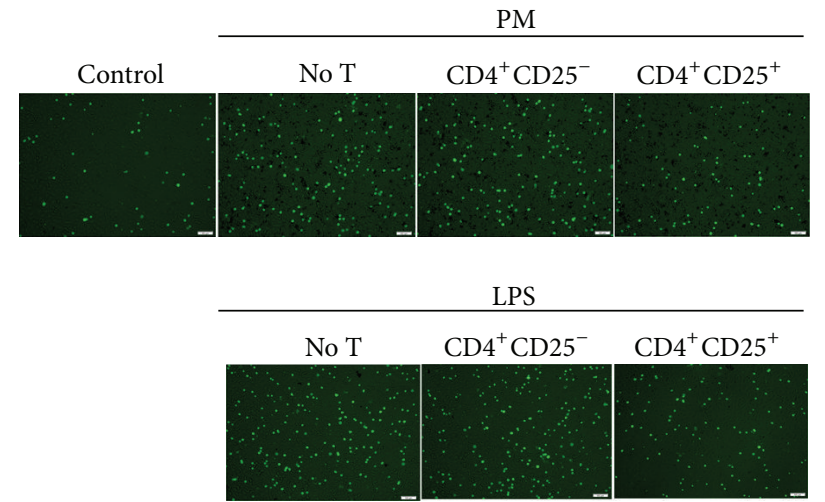

(a)

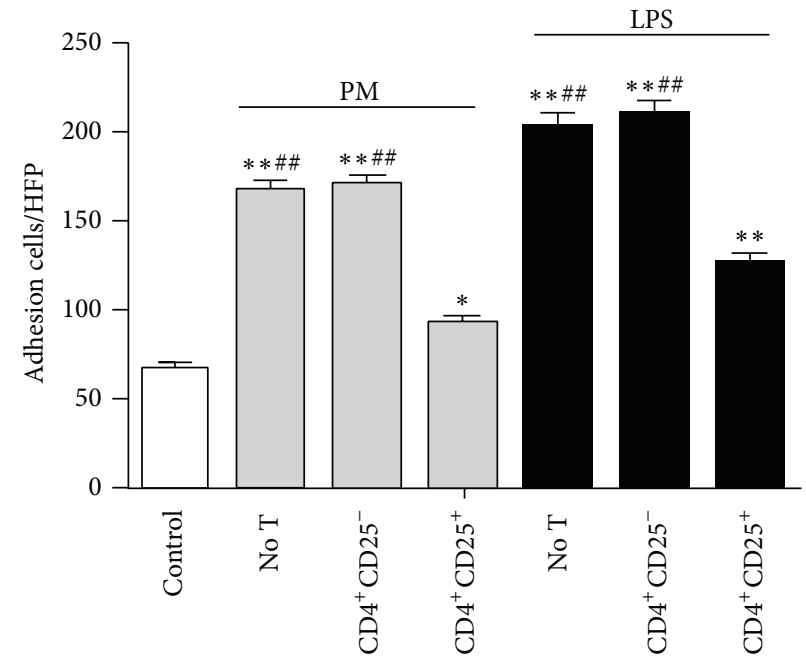

(b)

FIgurE 6: Tregs decrease the adhesion of THP-1 cells to endothelial cells. (a) Representative photomicrograph of THP-1 cells adhering to endothelial cells (ECs). THP-1 cells were identified by green fluorescence. Scale bar $=100 \mathrm{~nm}$. (b) The adhesion of THP-1 cells to ECs was determined by fluorescence microscopy. Data are expressed as means \pm SEM. ${ }^{*}$ indicates no $\mathrm{T}, \mathrm{CD} 44^{+} \mathrm{CD} 25^{-}$, or $\mathrm{CD} 4{ }^{+} \mathrm{CD} 25^{+}$versus control; ${ }^{\#}$ indicates no $\mathrm{T}$ or $\mathrm{CD} 4{ }^{+} \mathrm{CD} 25^{-}$versus $\mathrm{CD} 4{ }^{+} \mathrm{CD} 25^{+} .{ }^{*} \mathrm{P}<0.05,{ }^{* *} \mathrm{P}<0.01$, and ${ }^{\# \#} \mathrm{P}<0.01$. Experiments were repeated 4 times.
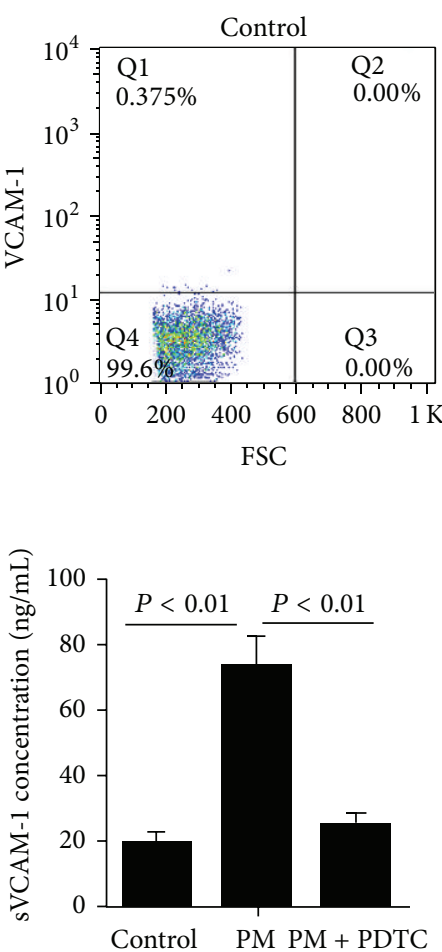

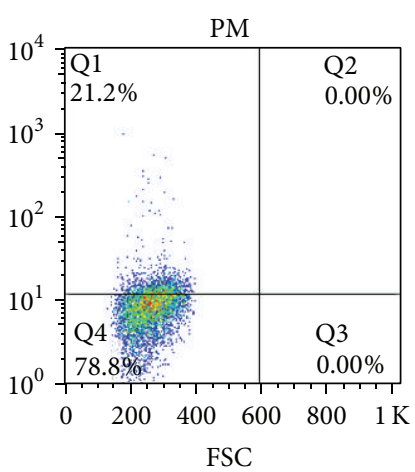

(a)

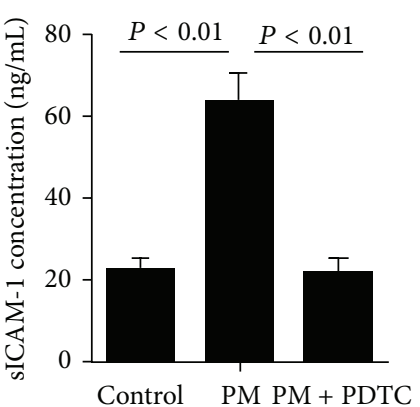

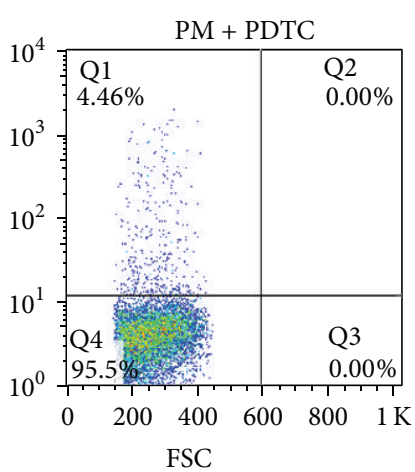

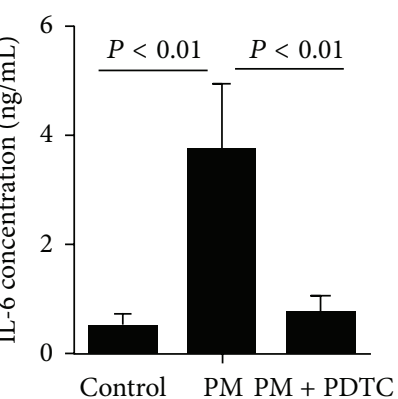

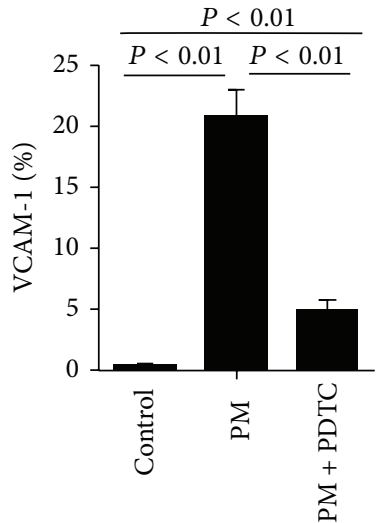

(b)

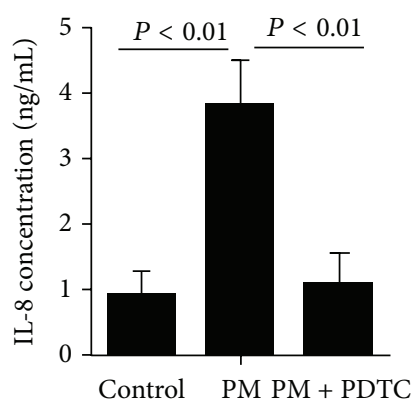

(c)

FIgURE 7: PDTC inhibits PM-induced inflammatory responses. HUVECs were pretreated for 30 min with the NF- $\kappa \mathrm{B}$ inhibitor PDTC $(10 \mu \mathrm{mol} / \mathrm{L})$ before stimulation with PM $(100 \mu \mathrm{g} / \mathrm{mL})$ for $24 \mathrm{~h}$. The adhesion molecules and inflammatory cytokines were detected by flow cytometry and Elisa. (a) Dot plots showing the percentages of VCAM-1 expression in HUVECs. (b) The VCAM-1 expression in different groups of HUVECs. (c) The concentration of sVCAM-1, sICAM-1, IL-6, and IL-8 in the supernatants from different groups of HUVECs. Data are expressed as means \pm SEM of 5 independent experiments. 


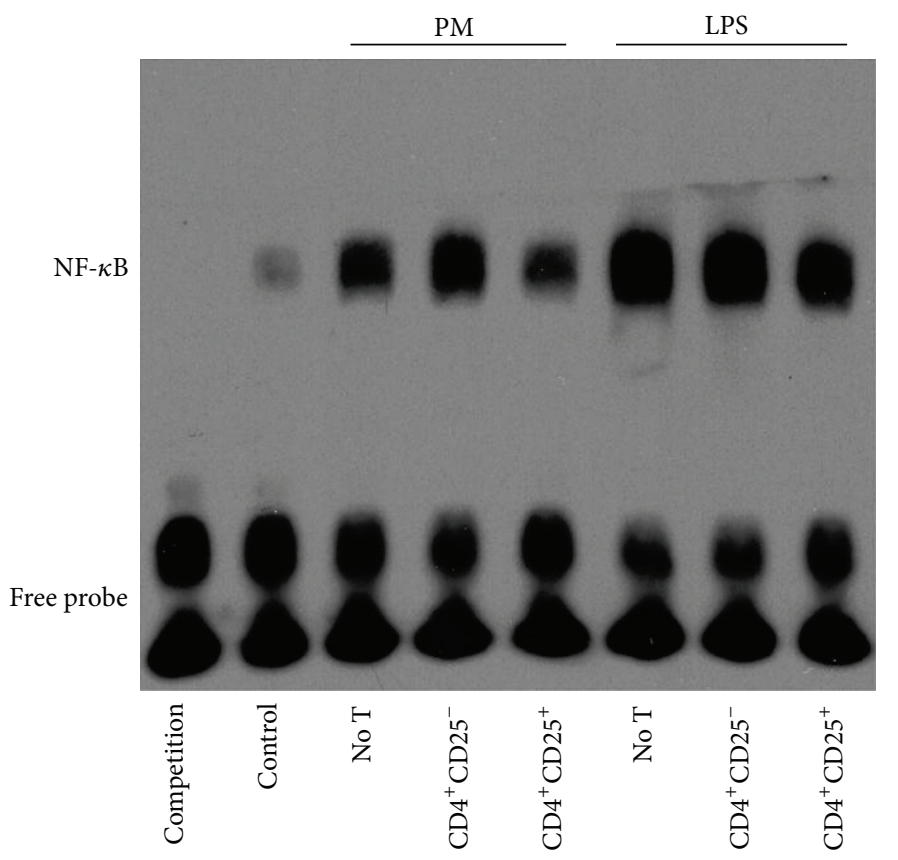

(a)

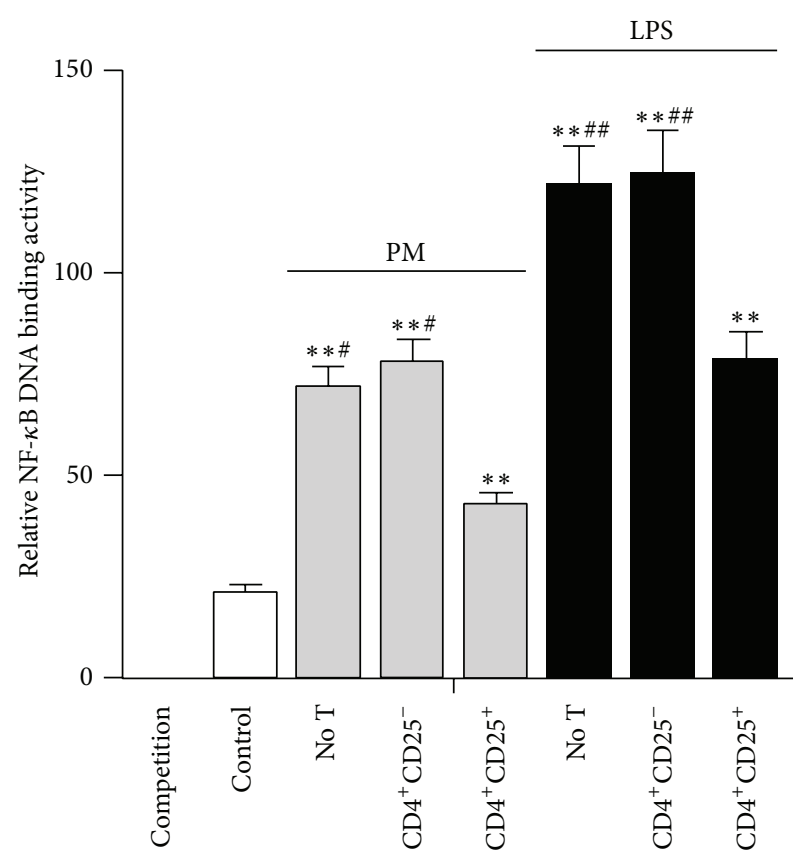

(b)

FIGURE 8: Tregs downregulate NF- $\kappa$ B activation in HUVECs impaired by PM. The electrophoretic mobility shift assay (EMSA) was conducted with nuclear proteins isolated from different HUVEC cultures to detect the NF- $\kappa$ B activity. (a) Representative EMSA results. (b) The DNAbinding activity of NF- $\kappa$ B in different groups determined by the relative measurement method. Data are expressed as means \pm SEM. ${ }^{*}$ indicates no $\mathrm{T}, \mathrm{CD} 4{ }^{+} \mathrm{CD} 25^{-}$, or $\mathrm{CD} 4{ }^{+} \mathrm{CD} 25^{+}$versus control; ${ }^{\#}$ indicates no $\mathrm{T}$ or $\mathrm{CD} 4{ }^{+} \mathrm{CD} 25^{-}$versus $\mathrm{CD} 4^{+} \mathrm{CD} 25^{+}$. ${ }^{* *} P<0.01,{ }^{\#} P<0.05$, and ${ }^{\# \#} P<$ 0.01 . Experiments were repeated 4 times.

To test whether NF- $\kappa$ B was involved in PM-induced inflammatory responses, we used the NF- $\kappa \mathrm{B}$ specific inhibitor PDTC to treat cells before PM stimulation. Form Figure 7, we demonstrated that PM-stimulated inflammatory responses were almost completely inhibited after PTDC treatment, indicating that NF- $\kappa \mathrm{B}$ activity might play an important role in PM-mediated inflammatory responses.

3.7. Tregs Downregulate PM-Induced NF- $\kappa B$ Activation in HUVECs. In our study, the NF- $\kappa \mathrm{B}$ activity in HUVECs after $\mathrm{PM} / \mathrm{LPS}$ treatment was determined by the EMSA assay using biotin-labeled oligonucleotide probes specific for the NF- $\kappa \mathrm{B}$ binding sites. In agreement with the above results including upregulated levels of adhesion molecules and inflammatory cytokines, the NF- $\kappa \mathrm{B}$ activity was increased in HUVECs without $\mathrm{T}$ cells after PM or LPS stimulation, compared to the control $(P<0.01$; Figure 8$)$. In contrast, the decreased inflammatory responses were reflected at the transcriptional level by an obviously reduced NF- $\kappa \mathrm{B}$ upregulation on PM/LPS stimulation from Tregs-treated HUVECs $(P<$ $0.01)$, whereas no difference was observed in Teff-treated HUVECs $(P>0.05$; Figure 8$)$.

\subsection{Treg-Mediated Suppression of HUVECs Inflammatory} Responses Is Mediated by Cell Contact and Soluble Factors. To explore whether suppression of inflammatory responses of HUVECs exposed to PM depended on cell contact or soluble factors, we cultured HUVECs without T cells, with Treg cells in the presence of anti-CD3 mAbs in either a coculture or a TW system. After 48 hours of culture, the top compartments were removed, and the HUVECs in the lower well were treated with PM for 24 hours. By blocking physical contact between HUVECs and Tregs (TW), the suppression of adhesion molecules (VCAM-1 and ICAM-1) and inflammatory cytokines (IL-6 and IL-8) production was obviously decreased compared with coculture system (Figures 9(b), $9(\mathrm{c})$, and $9(\mathrm{~d})$ ). This partial reversal of suppression could be owing to the requirement of cell contact between Tregs and PM-exposed HUVECs.

It is reported that activated Tregs could produce antiinflammatory cytokines, such as IL-10 and TGF- $\beta 1$ [22]. What is more, we also found that the concentrations of IL-10 and TGF- $\beta 1$ in the Tregs system was higher than that in other systems $(P<0.01$; Figure $9(\mathrm{a}))$. To investigate whether IL-10 or TGF- $\beta 1$ could be involved in the suppression of Tregs, the neutralizing experiments were conducted. Anti-IL-10, antiTGF- $\beta 1$, or isotype mAbs was added to the lower well of TW system. After treatment with anti-IL-10 mAbs or antiTGF- $\beta 1$, the inhibitory effects were significantly decreased; furthermore, the suppression of inflammatory responses in HUVECs was completely abolished when both anti-IL-10 and anti-TGF- $\beta 1 \mathrm{mAbs}$ were added, while the isotype mAbs had no effect (Figures 9(b), 9(c), and 9(d)).

\section{Discussion}

Abundant epidemiological evidence indicates that PM, particularly $\mathrm{PM}_{2.5}$, is a major risk factor with serious 


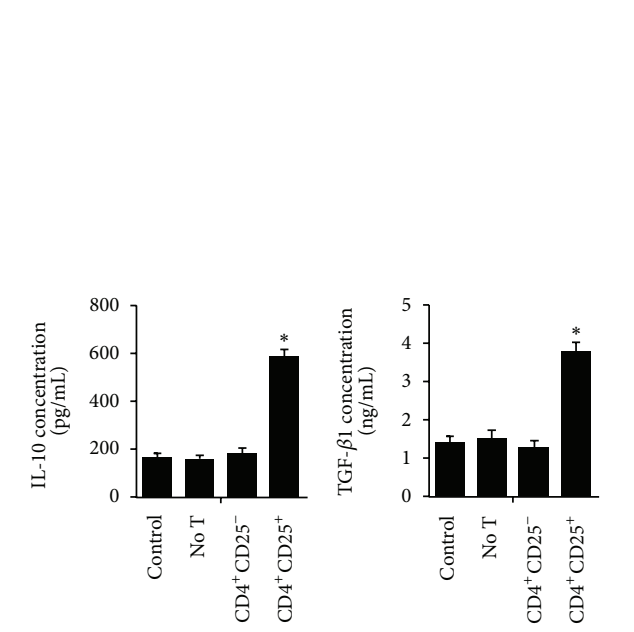

(a)

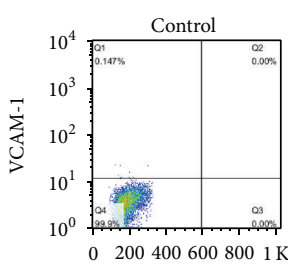

FSC

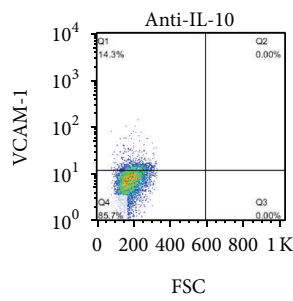

FSC

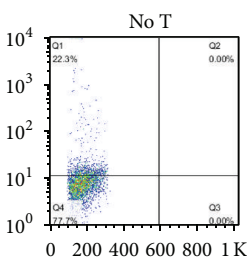

FSC

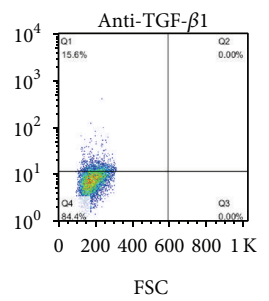

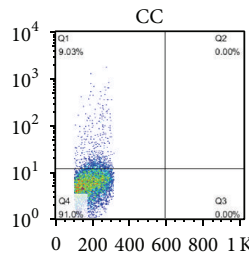

FSC

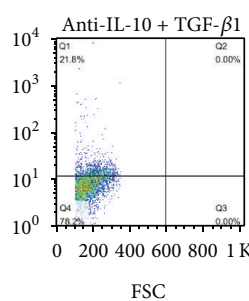

FSC

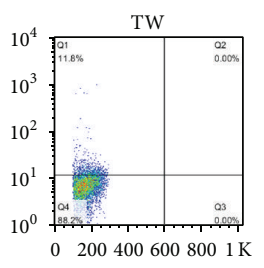

FSC

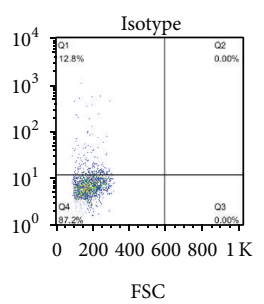

(b)

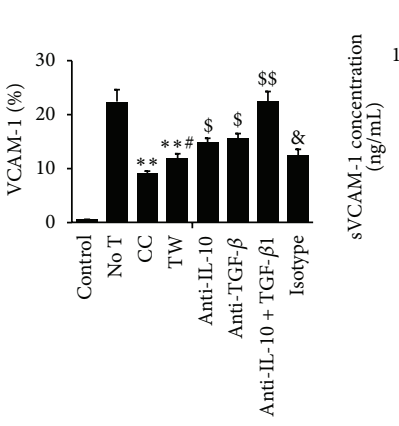

(c)

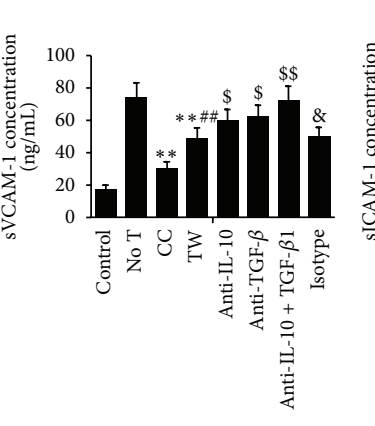

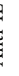
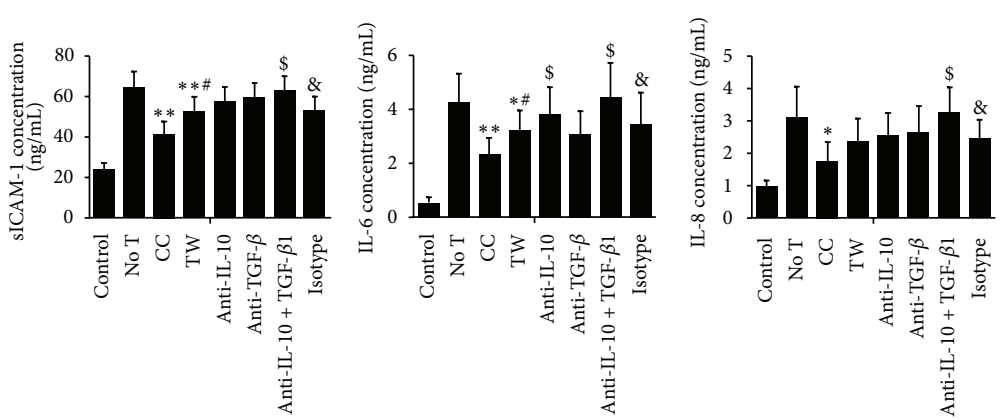

(d)

FIGURE 9: The mechanisms of Tregs-mediated suppression of HUVECs exposed to PM. HUVECs were cultured without T cells (no T) or with Tregs in the presence of anti-CD3 mAbs in either a coculture (CC) or a TW system. After 48 hours of culture, the inserts were removed and HUVECs in the lower well were stimulated with PM. In some experiments, IL-10, TGF- $\beta 1$, IL- 10 + TGF- $\beta 1$, or isotype mAbs was added to the lower well. The adhesion molecules and cytokines were detected by flow cytometry and Elisa. (a) The concentrations of IL-10 and TGF- $\beta 1$ in the supernatants from different groups. Data are expressed as means \pm SEM of 3 independent experiments. ${ }^{*} P<0.01$. (b) Dot plots showing the percentages of VCAM-1 expression in HUVECs. (c) The VCAM-1 expression in different groups of HUVECs. (d) The concentration of sVCAM-1, sICAM-1, IL-6, and IL-8 in the supernatants from different groups of HUVECs. Data are expressed as means \pm SEM of 4 independent experiments. ${ }^{*}$ indicates CC or TW versus no T; ${ }^{*}$ indicates TW versus CC; ${ }^{\$}$ indicates versus TW; ${ }^{*}$ indicates isotype versus TW. ${ }^{*} P<0.05,{ }^{* *} P<0.01,{ }^{\#} P<0.05,{ }^{\# \#} P<0.01,{ }^{\$} P<0.05,{ }^{\$} P<0.01$, and ${ }^{\&} P>0.05$.

consequences on the cardiovascular system [3, 23-26]. Because of its small size, $\mathrm{PM}_{2.5}$ could be inhaled into the lungs and translocate into the circulation, with potential direct effects on endothelial cells that lie in the innermost of blood vessels. In the present study, HUVECs were used to explore the effects of fine particles on endothelial inflammatory responses, and, for intervention studies, Treg cells isolated from healthy volunteers were employed. Consistent with previous studies, our results show that fine particles not only induced the expression of adhesion molecules and inflammatory cytokines in a concentration-dependent manner in HUVECs but also increased the adhesion of THP- 1 cells to endothelial cells mainly via NF- $\kappa$ B activation. Importantly, Treg cells were able to protect fine particlesinduced inflammatory responses and downregulate NF- $\kappa \mathrm{B}$ activation in HUVECs via cell contact with PM-impaired HUVECs and soluble factors (mainly IL-10 and TGF- $\beta 1$ ).
The endothelial barrier functions play an important role in regulating the vascular tone, cell adhesion, and vessel wall inflammation [27]. The expression levels of ICAM1 and VCAM-1 on the membrane of endothelial cells are important markers of the activation of the endothelium [28]. These cell adhesion molecules mediate the binding of leukocytes to ECs and thereby the recruitment of leukocytes to the interstitium of the tissue [29]. The recruitment of inflammatory cells is considered the first step towards the development of atherosclerosis. Previously, $\mathrm{PM}_{2.5}$ and $\mathrm{PM}_{10}$ have been reported to induce the expression of ICAM-1 and VCAM-1 in endothelial cells $[10,12,13]$. In our study, urban fine particulate matter $(<4 \mu \mathrm{m}$; SRM2786) instead of $\mathrm{PM}_{2.5}$ was used to stimulate HUVECs. We found that the fine particles obviously induced both mRNA and protein expression of VCAM-1 and ICAM-1 in HUVECs, which may contribute to PM-accelerated atherosclerosis. Some animal 
experiments suggested that an increase in Treg cell numbers and functions is related to the reduction of atherosclerotic plaques [30-35]. In addition, Tregs have also been found to protect ox-LDL/LPS-induced expression of VCAM-1 in HUVECs [18]. Consistent with previous studies, our results show that Treg cells, but not Teff cells, significantly decreased PM-induced expression of adhesion molecules (VCAM-1 and ICAM-1) in the HUVECs.

Next, to determine whether fine particles induce the expression of adhesion molecules after $24 \mathrm{~h}$ of treatment, the adhesion of THP-1 cells to endothelial cells was examined. We found that compared to the control, the adhesion of THP-1 cells to PM-treated HUVECs was obviously increased, consistent with previously reported results $[10,12]$. In contrast, coculture with Treg cells was able to reduce the adhesion, whereas Teff cells only had a minor effect. The adhesion of leukocytes to ECs and subsequent transmigration of monocytes across the endothelium are considered important steps for the initiation of atherosclerosis. Sun et al. demonstrated that long-term exposure of ApoE-/- mice to low concentrations of $\mathrm{PM}_{2.5}$ increased plaque areas and macrophage infiltration [4]. Together, these results not only indicate that fine particles induce the activation of HUVECs and result in monocyte adhesion due to increased expression of adhesion molecules but also imply that fine particles may participate in the development of atherosclerosis. More importantly, our study suggests that Treg cells play a role in attenuating fine particles-mediated vascular inflammation and atherosclerosis.

Fine particles may induce inflammatory responses in human macrophages [36], human epithelial lung cells [37], and human endothelial cells $[11,15]$. In this study, increased mRNA and protein expression of IL- 6 and IL- 8 demonstrates that the fine particles caused inflammatory responses in HUVECs. On the other hand, Treg cells-treated HUVECs showed significantly decreased mRNA and protein expression of IL-6 and IL-8, suggesting that Tregs may protect fine particles-induced inflammatory responses. Based on these results, we conclude that fine particles induced the expression of adhesion molecules and inflammatory cytokines in HUVECs and that these effects were alleviated by treatment with Tregs.

$\mathrm{NF}-\kappa \mathrm{B}$ signaling is an important pathway that mediates proinflammatory responses $[38,39]$. The role of NF$\kappa \mathrm{B}$ in $\mathrm{PM}$-induced inflammatory responses is supported by emerging evidence. Specifically, fine particles derived from diesel engines (diesel exhaust particles) were shown to activate NF- $\kappa$ B in human bronchial epithelium [40-42]. Studies suggested that NF- $\kappa \mathrm{B}$ activation induced by diesel exhaust particles is related to the expression of inflammatory chemokines, such as IL- 8 , monocyte chemoattractant protein-1, and adhesion molecules [43]. In addition, diesel ultrafine particles (UFPs) may also mediate proinflammatory responses via $\mathrm{NF}-\kappa \mathrm{B}$ activation in endothelial cells [43]. On the contrary, in human antimycobacterial immunity, the NF- $\kappa \mathrm{B}$ activity was suppressed by diesel exhaust particles, and consequently antimycobacterial immunity was impaired [44]. Therefore, fine particles may alter the NF- $\kappa$ B activity in a microenvironment-dependent fashion. In our study, after treatment with NF- $\kappa$ B specific inhibitor PDTC, fine particlesinduced inflammatory responses were almost completely abolished. Moreover, in agreement with increased expression of adhesion molecules and inflammatory cytokines, the EMSA results also showed that fine particles induced NF$\kappa \mathrm{B}$ activation in HUVECs. In addition, He et al. previously reported that Tregs downregulated ox-LDL/LPS-induced $\mathrm{NF}-\kappa \mathrm{B}$ activation in HUVECs [18]; similarly, our study demonstrates that Tregs dramatically decreased PM-induced NF- $\kappa$ B activation in HUVECs. Together, these findings imply that Treg cells may decrease fine particles-induced expression of adhesion molecules and inflammatory cytokines mainly by downregulating NF- $\kappa \mathrm{B}$ activation.

Some mechanisms about Treg-mediated inhibition that have been found consist of anti-inflammatory cytokines secreted by Treg cells or cell contact-dependent suppression [45]. In our study, TW experiments and neutralizing antibodies were used to explore the mechanisms of Tregmediated suppression of HUVECs. By blocking physical contact between Tregs and HUVECs (TW), the suppression of inflammatory responses was only partly reversed, indicating that cell contact played a role in Treg-mediated suppression. Moreover, in the supernatants of coculture system, the concentrations of IL-10 and TGF- $\beta 1$ were significantly increased, suggesting that anti-inflammatory cytokines might be required in Treg-mediated suppression. Thus, the reduced NF- $\kappa$ B activation in Treg-treated HUVECs may be partly owing to the increased concentrations of IL-10, because IL-10 could suppress NF- $\kappa$ B activation [46]. After treatment with both anti-IL-10 and TGF- $\beta 1 \mathrm{mAbs}$, the suppression of inflammatory responses in TW system was abolished. Therefore, it is speculated that the mechanisms including cell contact and anti-inflammatory cytokines contribute to suppression mediated by Tregs.

In summary, fine particles (SRM2786) may stimulate the expression of adhesion molecules and inflammatory cytokines via NF- $\kappa \mathrm{B}$ activation in HUVECs. More importantly, to the best of our knowledge, this present study is the first to demonstrate that Treg cells may protect PM-induced inflammatory responses and downregulate NF- $\kappa \mathrm{B}$ activation in HUEVCs via cell contact and anti-inflammatory cytokines in vitro. These findings may provide novel targets for treating PM-induced adverse health effects, especially cardiovascular diseases. Future studies are required to investigate the in vivo effects of Treg cells on fine particles-induced cardiovascular diseases, such as atherosclerosis, in animal models.

\section{Abbreviations}

PM: $\quad$ Particulate matter

HUVECs: Human umbilical vein endothelial cells

VCAM-1: Vascular cell adhesion molecule-1

ICAM-1: Intercellular adhesion molecule-1

THP-1: Human acute monocytic leukemia cells

EMSA: Electrophoretic mobility shift assay.

\section{Conflict of Interests}

The authors declare that they have no conflict of interests. 


\section{Authors' Contribution}

Wen-cai Zhang, Yan-ge Wang, and Zheng-feng Zhu contributed equally to this work.

\section{Acknowledgments}

This work was supported by Grants from National Basic Research Program of China (973 Program: 2011CB503806 to Long-xian Cheng) and National Natural Science Foundation of China (nos. 81172750 and 81370324 to Long-xian Cheng).

\section{References}

[1] C. A. Pope III, R. T. Burnett, M. J. Thun et al., "Lung cancer, cardiopulmonary mortality, and long-term exposure to fine particulate air pollution," Journal of the American Medical Association, vol. 287, no. 9, pp. 1132-1141, 2002.

[2] D. W. Dockery, "Epidemiologic study design for investigating respiratory health effects of complex air pollution mixtures," Environmental Health Perspectives, vol. 101, supplement 4, pp. 187-191, 1993.

[3] C. A. Pope III, R. T. Burnett, G. D. Thurston et al., "Cardiovascular mortality and long-term exposure to particulate air pollution: epidemiological evidence of general pathophysiological pathways of disease," Circulation, vol. 109, no. 1, pp. 71-77, 2004.

[4] Q. Sun, A. Wang, X. Jin et al., "Long-term air pollution exposure and acceleration of atherosclerosis and vascular inflammation in an animal model," Journal of the American Medical Association, vol. 294, no. 23, pp. 3003-3010, 2005.

[5] L. C. Chen and C. Nadziejko, "Effects of subchronic exposures to concentrated ambient particles (CAPs) in mice: V. CAPs exacerbate aortic plaque development in hyperlipidemic mice," Inhalation Toxicology, vol. 17, no. 4-5, pp. 217-224, 2005.

[6] Y.-C. Lei, J.-S. Hwang, C.-C. Chan, C.-T. Lee, and T.-J. Cheng, "Enhanced oxidative stress and endothelial dysfunction in streptozotocin-diabetic rats exposed to fine particles," Environmental Research, vol. 99, no. 3, pp. 335-343, 2005.

[7] H.-H. Tan, M. I. Fiel, Q. Sun et al., "Kupffer cell activation by ambient air particulate matter exposure may exacerbate nonalcoholic fatty liver disease," Journal of Immunotoxicology, vol. 6, no. 4, pp. 266-275, 2009.

[8] T. R. Nurkiewicz, D. W. Porter, M. Barger, V. Castranova, and M. A. Boegehold, "Particulate matter exposure impairs systemic microvascular endothelium-dependent dilation," Environmental Health Perspectives, vol. 112, no. 13, pp. 1299-1306, 2004.

[9] T. R. Nurkiewicz, D. W. Porter, M. Barger et al., "Systemic microvascular dysfunction and inflammation after pulmonary particulate matter exposure," Environmental Health Perspectives, vol. 114, no. 3, pp. 412-419, 2006.

[10] A. Montiel-Dávalos, E. Alfaro-Moreno, and R. López-Marure, "PM2.5 and PM10 induce the expression of adhesion molecules and the adhesion of monocytic cells to human umbilical vein endothelial cells," Inhalation Toxicology, vol. 19, supplement 1 , pp. 91-98, 2007.

[11] J. Zhao, Y. Xie, R. Jiang, H. Kan, and W. Song, "Effects of atorvastatin on fine particle-induced inflammatory response, oxidative stress and endothelial function in human umbilical vein endothelial cells," Human and Experimental Toxicology, vol. 30, no. 11, pp. 1828-1839, 2011.
[12] L. Forchhammer, S. Loft, M. Roursgaard et al., "Expression of adhesion molecules, monocyte interactions and oxidative stress in human endothelial cells exposed to wood smoke and diesel exhaust particulate matter," Toxicology Letters, vol. 209, no. 2, pp. 121-128, 2012.

[13] H. Frikke-Schmidt, M. Roursgaard, J. Lykkesfeldt, S. Loft, J. K. Nøjgaard, and P. Møller, "Effect of vitamin C and iron chelation on diesel exhaust particle and carbon black induced oxidative damage and cell adhesion molecule expression in human endothelial cells," Toxicology Letters, vol. 203, no. 3, pp. 181-189, 2011.

[14] Y. Mo, R. Wan, S. Chien, D. J. Tollerud, and Q. Zhang, "Activation of endothelial cells after exposure to ambient ultrafine particles: the role of NADPH oxidase," Toxicology and Applied Pharmacology, vol. 236, no. 2, pp. 183-193, 2009.

[15] S. Becker, L. A. Dailey, J. M. Soukup, S. C. Grambow, R. B. Devlin, and Y.-C. T. Huang, "Seasonal variations in air pollution particle-induced inflammatory mediator release and oxidative stress," Environmental Health Perspectives, vol. 113, no. 8, pp. 1032-1038, 2005.

[16] P. O. Bonetti, L. O. Lerman, and A. Lerman, "Endothelial dysfunction: a marker of atherosclerotic risk," Arteriosclerosis, Thrombosis, and Vascular Biology, vol. 23, no. 2, pp. 168-175, 2003.

[17] S. Sakaguchi, M. Ono, R. Setoguchi et al., "Foxp $3^{+} \mathrm{CD} 25^{+} \mathrm{CD} 4^{+}$ natural regulatory $\mathrm{T}$ cells in dominant self-tolerance and autoimmune disease," Immunological Reviews, vol. 212, pp. 827, 2006.

[18] S. He, M. Li, X. Ma, J. Lin, and D. Li, “CD $4^{+} \mathrm{CD} 25^{+}$Foxp $3^{+}$regulatory $\mathrm{T}$ cells protect the proinflammatory activation of human umbilical vein endothelial cells," Arteriosclerosis, Thrombosis, and Vascular Biology, vol. 30, no. 12, pp. 2621-2630, 2010.

[19] E. Zapata, J. L. Ventura, K. De La Cruz et al., "Dehydroepiandrosterone inhibits the proliferation of human umbilical vein endothelial by enhancing the expression of $\mathrm{p} 53$ and $\mathrm{p} 21$, restricting the phosphorylation of retinoblastoma protein, and is androgen- and estrogen-receptor independent," The FEBS Journal, vol. 272, no. 6, pp. 1343-1353, 2005.

[20] M. M. Tiemessen, A. L. Jagger, H. G. Evans, M. J. C. Van Herwijnen, S. John, and L. S. Taams, "CD $4^{+} \mathrm{CD} 25^{+} \mathrm{Foxp}^{+}$ regulatory $\mathrm{T}$ cells induce alternative activation of human monocytes/macrophages," Proceedings of the National Academy of Sciences of the United States of America, vol. 104, no. 49, pp. 19446-19451, 2007.

[21] M. S. Smith, E. R. Bivins-Smith, A. M. Tilley et al., "Roles of phosphatidylinositol 3-kinase and NF- $\kappa$ B in human cytomegalovirus-mediated monocyte diapedesis and adhesion: strategy for viral persistence," Journal of Virology, vol. 81, no. 14, pp. 7683-7694, 2007.

[22] H. Liu, B. Hu, D. Xu, and F. Y. Liew, "CD $4{ }^{+} \mathrm{CD} 25^{+}$regulatory T cells cure murine colitis: the role of IL-10, TGF-beta, and CTLA4," Journal of Immunology, vol. 171, no. 10, pp. 5012-5017, 2003.

[23] D. W. Dockery, C. A. Pope III, X. Xu et al., "An association between air pollution and mortality in six U.S. cities," The New England Journal of Medicine, vol. 329, no. 24, pp. 1753-1759, 1993.

[24] G. Hoek, B. Brunekreef, S. Goldbohm, P. Fischer, and P. A. Van Den Brandt, "Association between mortality and indicators of traffic-related air pollution in the Netherlands: a cohort study," The Lancet, vol. 360, no. 9341, pp. 1203-1209, 2002.

[25] C. A. Pope III, J. B. Muhlestein, H. T. May, D. G. Renlund, J. L. Anderson, and B. D. Horne, "Ischemic heart disease 
events triggered by short-term exposure to fine particulate air pollution," Circulation, vol. 114, no. 23, pp. 2443-2448, 2006.

[26] K. A. Miller, D. S. Siscovick, L. Sheppard et al., "Long-term exposure to air pollution and incidence of cardiovascular events in women," The New England Journal of Medicine, vol. 356, no. 5, pp. 447-458, 2007.

[27] N. R. Madamanchi, A. Vendrov, and M. S. Runge, "Oxidative stress and vascular disease," Arteriosclerosis, Thrombosis, and Vascular Biology, vol. 25, no. 1, pp. 29-38, 2005.

[28] T. M. Carlos and J. M. Harlan, "Leukocyte-endothelial adhesion molecules," Blood, vol. 84, no. 7, pp. 2068-2101, 1994.

[29] W. C. Aird, "Phenotypic heterogeneity of the endothelium: I. Structure, function, and mechanisms," Circulation Research, vol. 100, no. 2, pp. 158-173, 2007.

[30] H. Ait-Oufella, B. L. Salomon, S. Potteaux et al., "Natural regulatory $\mathrm{T}$ cells control the development of atherosclerosis in mice," Nature Medicine, vol. 12, no. 2, pp. 178-180, 2006.

[31] A. Mor, D. Planer, G. Luboshits et al., "Role of naturally occurring $\mathrm{CD} 4{ }^{+} \mathrm{CD} 25^{+}$regulatory $\mathrm{T}$ cells in experimental atherosclerosis," Arteriosclerosis, Thrombosis, and Vascular Biology, vol. 27, no. 4, pp. 893-900, 2007.

[32] S. Steffens, F. Burger, G. Pelli et al., "Short-term treatment with anti-CD3 antibody reduces the development and progression of atherosclerosis in mice," Circulation, vol. 114, no. 18, pp. 19771984, 2006.

[33] N. Sasaki, T. Yamashita, M. Takeda et al., "Oral anti-CD3 antibody treatment induces regulatory $t$ cells and inhibits the development of atherosclerosis in mice," Circulation, vol. 120, no. 20, pp. 1996-2005, 2009.

[34] E. A. Heller, E. Liu, A. M. Tager et al., "Chemokine CXCL10 promotes atherogenesis by modulating the local balance of effector and regulatory T cells," Circulation, vol. 113, no. 19, pp. 2301-2312, 2006.

[35] T. van Es, G. H. M. van Puijvelde, A. C. Foks et al., "Vaccination against Foxp $3^{+}$regulatory T cells aggravates atherosclerosis," Atherosclerosis, vol. 209, no. 1, pp. 74-80, 2010.

[36] C. F. A Vogel, J. Garcia, D. Wu et al., "Activation of inflammatory responses in human U937 macrophages by particulate matter collected from dairy farms: an in vitro expression analysis of pro-inflammatory markers," Environmental Health, vol. 11, no. 1, article 17, 2012.

[37] Z. Dagher, G. Garçon, P. Gosset et al., "Pro-inflammatory effects of Dunkerque city air pollution particulate matter 2.5 in human epithelial lung cells (L132) in culture," Journal of Applied Toxicology, vol. 25, no. 2, pp. 166-175, 2005.

[38] P. J. Barnes and M. Karin, "Nuclear factor $-\kappa \mathrm{B}-\mathrm{a}$ pivotal transcription factor in chronic inflammatory diseases," The New England Journal of Medicine, vol. 336, no. 15, pp. 1066-1071, 1997.

[39] T. Collins, M. A. Read, A. S. Neish, M. Z. Whitley, D. Thanos, and T. Maniatis, "Transcriptional regulation of endothelial cell adhesion molecules: NF- $\kappa$ B and cytokine-inducible enhancers," The FASEB Journal, vol. 9, no. 10, pp. 899-909, 1995.

[40] J. Pourazar, A. Blomberg, F. J. Kelly et al., "Diesel exhaust increases EGFR and phosphorylated C-terminal Tyr 1173 in the bronchial epithelium," Particle and Fibre Toxicology, vol. 5, article 8, 2008.

[41] H. Takizawa, S. Abe, H. Okazaki et al., "Diesel exhaust particles upregulate eotaxin gene expression in human bronchial epithelial cells via nuclear factor- $\kappa \mathrm{B}$-dependent pathway," The American Journal of Physiology -Lung Cellular and Molecular Physiology, vol. 284, no. 6, pp. L1055-L1062, 2003.
[42] H. Takizawa, T. Ohtoshi, S. Kawasaki et al., "Diesel exhaust particles induce NF- $\kappa \mathrm{B}$ activation in human bronchial epithelial cells in vitro: importance in cytokine transcription," Journal of Immunology, vol. 162, no. 8, pp. 4705-4711, 1999.

[43] R. Li, Z. Ning, R. Majumdar et al., "Ultrafine particles from diesel vehicle emissions at different driving cycles induce differential vascular pro-inflammatory responses: implication of chemical components and NF- $\kappa \mathrm{B}$ signaling," Particle and Fibre Toxicology, vol. 7, article 6, 2010.

[44] S. Sarkar, Y. Song, S. Sarkar et al., "Suppression of the NF$\kappa \mathrm{B}$ pathway by diesel exhaust particles impairs human antimycobacterial immunity," Journal of Immunology, vol. 188, no. 6, pp. 2778-2793, 2012.

[45] S. Sakaguchi, T. Yamaguchi, T. Nomura, and M. Ono, "Regulatory T cells and immune tolerance," Cell, vol. 133, no. 5, pp. 775-787, 2008.

[46] A. B. Lentsch, T. P. Shanley, V. Sarma, and P. A. Ward, "In vivo suppression of NF- $\kappa \mathrm{B}$ and preservation of $\mathrm{I} \kappa \mathrm{B} \alpha$ by interleukin10 and interleukin-13," The Journal of Clinical Investigation, vol. 100, no. 10, pp. 2443-2448, 1997. 


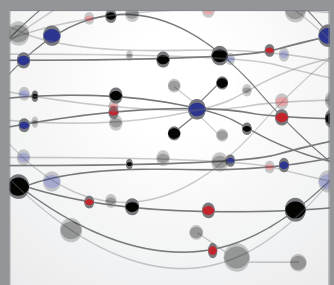

The Scientific World Journal
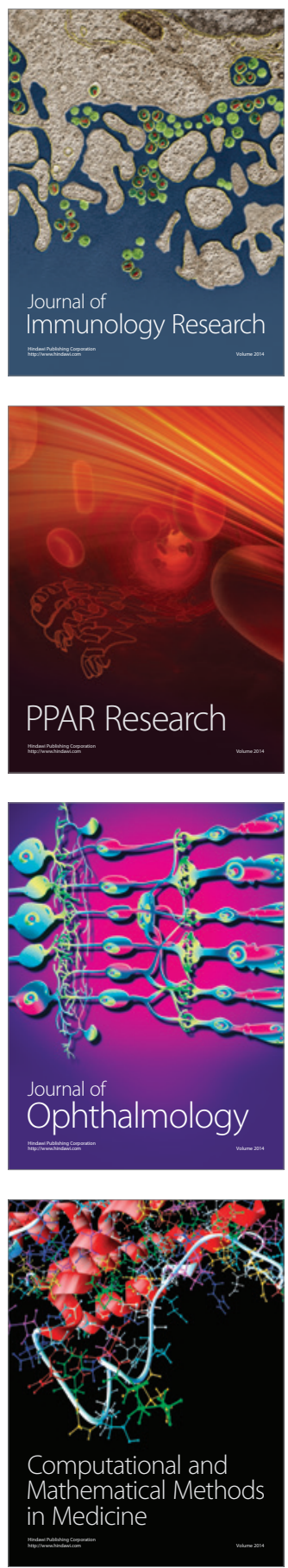

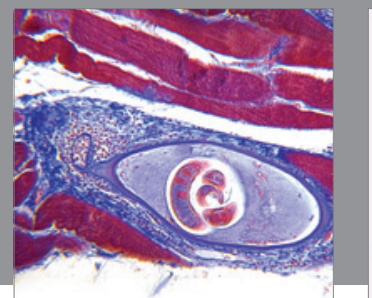

Gastroenterology

Research and Practice
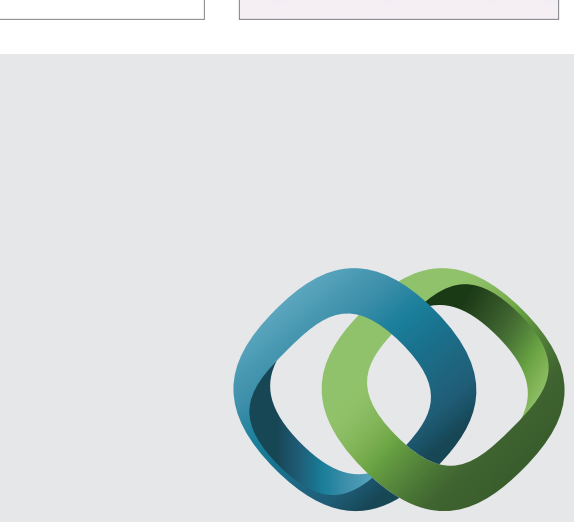

\section{Hindawi}

Submit your manuscripts at

http://www.hindawi.com
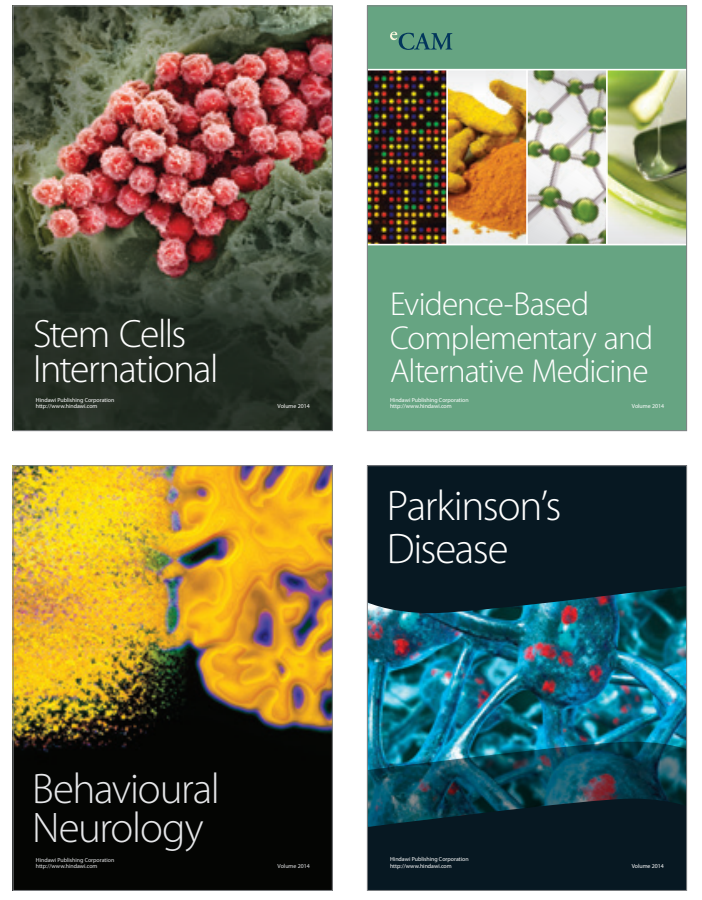
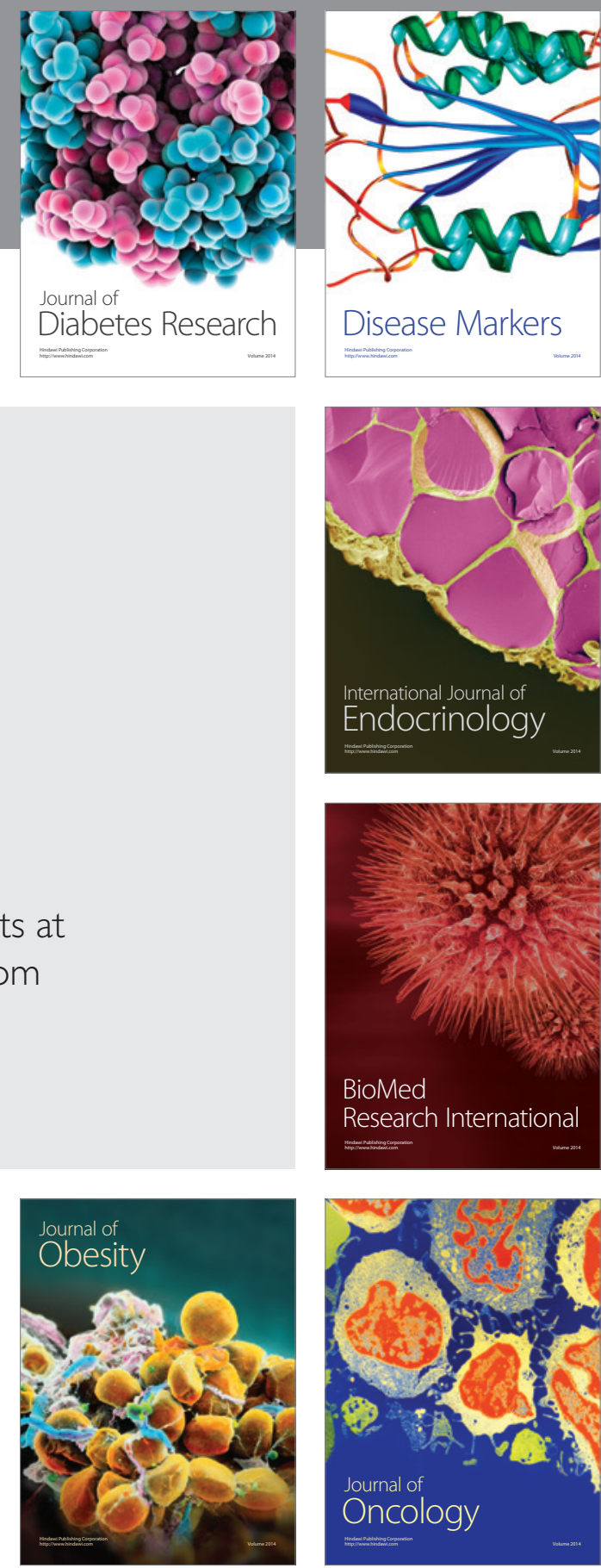

Disease Markers
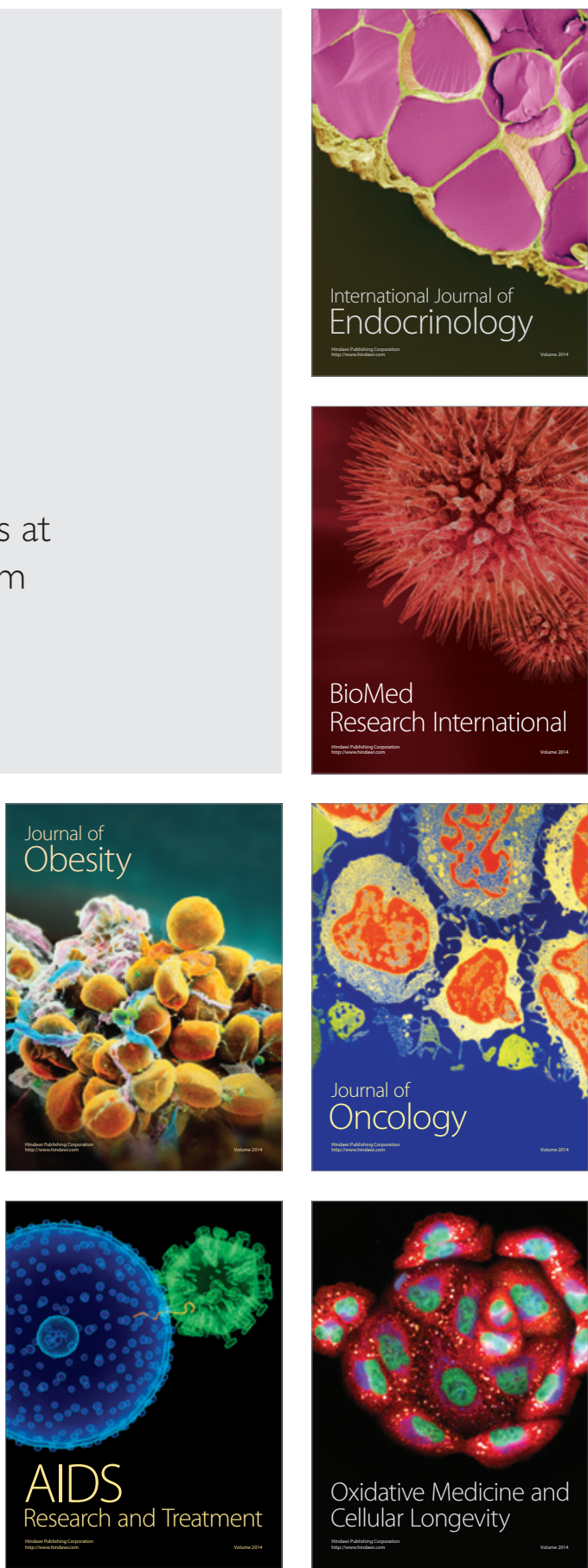